\title{
Regional-scale simulations of fungal spore aerosols using an emission parameterization adapted to local measurements of fluorescent biological aerosol particles
}

\author{
M. Hummel ${ }^{1, *}$, C. Hoose ${ }^{1}$, M. Gallagher ${ }^{2}$, D. A. Healy ${ }^{3}$, J. A. Huffman ${ }^{4}$, D. O'Connor ${ }^{3}$, U. Pöschl ${ }^{5}$, C. Pöhlker ${ }^{5}$, \\ N. H. Robinson ${ }^{6}$, M. Schnaiter ${ }^{1}$, J. R. Sodeau ${ }^{3}$, M. Stengel ${ }^{7}$, E. Toprak ${ }^{1}$, and H. Vogel $^{1}$ \\ ${ }^{1}$ Institute of Meteorology and Climate Research, Karlsruhe Institute of Technology, Karlsruhe, Germany \\ ${ }^{2}$ The Centre for Atmospheric Sciences, The University of Manchester, Manchester, United Kingdom \\ ${ }^{3}$ Centre for Research into Atmospheric Chemistry, Department of Chemistry, University College Cork, Cork, Ireland \\ ${ }^{4}$ Department of Chemistry \& Biochemistry, University of Denver, Denver, Colorado, USA \\ ${ }^{5}$ Biogeochemistry Department and Multiphase Chemistry Department, Max Planck Institute for Chemistry, Mainz, Germany \\ ${ }^{6}$ Met Office, Exeter, United Kingdom \\ ${ }^{7}$ Deutscher Wetterdienst (DWD), Offenbach, Germany \\ *now at: Department of Geosciences, University of Oslo, Oslo, Norway
}

Correspondence to: M. Hummel (matthias.hummel@kit.edu) and C. Hoose (corinna.hoose@kit.edu)

Received: 18 February 2014 - Published in Atmos. Chem. Phys. Discuss.: 16 April 2014

Revised: 21 March 2015 - Accepted: 4 May 2015 - Published: 4 June 2015

\begin{abstract}
Fungal spores as a prominent type of primary biological aerosol particles (PBAP) have been incorporated into the COSMO-ART (Consortium for Small-scale ModellingAerosols and Reactive Trace gases) regional atmospheric model. Two literature-based emission rates for fungal spores derived from fungal spore colony counts and chemical tracer measurements were used as a parameterization baseline for this study. A third, new emission parameterization for fluorescent biological aerosol particles (FBAP) was adapted to field measurements from four locations across Europe. FBAP concentrations can be regarded as a lower estimate of total PBAP concentrations. Size distributions of FBAP often show a distinct mode at approx. $3 \mu \mathrm{m}$, corresponding to a diameter range characteristic for many fungal spores. Previous studies for several locations have suggested that FBAP are in many cases dominated by fungal spores. Thus, we suggest that simulated FBAP and fungal spore concentrations obtained from the three different emission parameterizations can be compared to FBAP measurements. The comparison reveals that simulated fungal spore concentrations based on literature emission parameterizations are lower than measured FBAP concentrations. In agreement with the measurements, the model results show a diurnal cycle in simulated fungal
\end{abstract}

spore concentrations, which may develop partially as a consequence of a varying boundary layer height between day and night. Temperature and specific humidity, together with leaf area index (LAI), were chosen to drive the new emission parameterization which is fitted to the FBAP observations. The new parameterization results in similar root mean square errors (RMSEs) and correlation coefficients compared to the FBAP observations as the previously existing fungal spore emission parameterizations, with some improvements in the bias. Using the new emission parameterization on a model domain covering western Europe, FBAP in the lowest model layer comprise a fraction of $15 \%$ of the total aerosol mass over land and reach average number concentrations of $26 \mathrm{~L}^{-1}$. The results confirm that fungal spores and biological particles may account for a major fraction of supermicron aerosol particle number and mass concentration over vegetated continental regions and should thus be explicitly considered in air quality and climate studies. 


\section{Introduction}

Particles emitted from biological sources are a miscellaneous and omnipresent group of the Earth's atmospheric aerosols (Elbert et al., 2007; Després et al., 2012). These primary biological aerosol particles (PBAP) can be transported over large distances and their impacts are studied by various fields of research, such as atmospheric science, agricultural research, biogeography, and public health (Burrows et al., 2009). PBAP are solid airborne particles of biological origin and include microorganisms or reproductive units (e.g., bacteria, fungi, spores, pollen or viruses) as well as excretions and fragments of biological organisms (e.g., detritus, microbial fragments or leaf debris) (Després et al., 2012). Typical sizes range from $<0.3 \mu \mathrm{m}$ for viruses to diameters of single bacteria $(0.25-3 \mu \mathrm{m})$, bacteria agglomerates $(3-8 \mu \mathrm{m})$, fungal spores $(1-30 \mu \mathrm{m})$, and up to $10-100 \mu \mathrm{m}$ for airborne pollen (Jones and Harrison, 2004; Shaffer and Lighthart, 1997; Després et al., 2012).

The share of atmospheric aerosol composition belonging to PBAP is large and possibly underestimated (Jaenicke et al., 2007), but is also very uncertain. Estimates of relative PBAP fraction from global models and local measurements reveal large differences between reports. On one hand, the calculated number concentration of PBAP (zonal annual mean surface concentrations of $\left.10^{-2}-10^{-1} \mathrm{~cm}^{-3}\right)$ is less than that of mineral dust $\left(65 \mathrm{~cm}^{-3}\right)$ or soot $\left(1000 \mathrm{~cm}^{-3}\right)$ concentrations by several orders of magnitude (Hoose et al., 2010b). Modeling studies have yielded global source strengths of $\sim 10 \mathrm{Tg} \mathrm{yr}^{-1}$ (plant debris and fungal spores, Winiwarter et al., 2009), $56 \mathrm{Tg} \mathrm{yr}^{-1}$ (all PBAP types; Penner, 1995), $78 \mathrm{Tg} \mathrm{yr}^{-1}$ (bacteria, fungal spores and pollen; Hoose et al., 2010a), $164 \mathrm{Tg} \mathrm{yr}^{-1}$ (all PBAP types; Mahowald et al., 2008) and $312 \mathrm{Tg} \mathrm{yr}^{-1}$ (bacteria, fungal spores and pollen; Jacobson and Streets, 2009). On the other hand, measurements of continental boundary layer air in remote vegetated regions indicate that the mass fraction of PBAP in the coarse particle size range can be as high as $\sim 30 \%(>0.2 \mu \mathrm{m}$, Siberia; Matthias-Maser et al., 2000) or $65-85 \%$ (> $1 \mu \mathrm{m}$, Amazonia; Martin et al., 2010; Pöschl et al., 2010; Huffman et al., 2012).

Like all other aerosol particles, PBAP can influence the Earth's climate by forcing the radiation budget directly (by absorbing or scattering radiation) and indirectly (by affecting cloud microphysics) (Forster et al., 2007). The direct PBAP effect on climate is difficult to estimate, because atmospheric PBAP concentration can vary by several orders of magnitude depending on time and location. Describing the radiative properties of PBAP is complicated, because their size ranges from fine to coarse (up to $100 \mu \mathrm{m}$ in diameter) and in many cases their shapes are non-spherical and not accurately known. Hence, the applicability of Mie scattering theory is limited (Després et al., 2012). However, the direct PBAP effect on global and regional climate is generally assumed to be small due to low average concentrations, in contrast to the numbers of sub-micron absorbing and scattering aerosols. The indirect PBAP effect on climate is caused by PBAP that act as cloud condensation nuclei $(\mathrm{CCN})$ and/or as ice nuclei (IN). Generally, changing aerosol populations (e.g., increasing nuclei concentrations or behavior) can alter the microphysical properties of clouds, thus influencing the climate system (Forster et al., 2007). Most PBAP are assumed to be good CCN, because their surface area is large compared to most other aerosol species (Petters and Kreidenweis, 2007; Ariya et al., 2009) and thus may act as so-called giant CCN (Pöschl et al., 2010). For these particles, the Kelvin effect can be neglected when describing water vapor condensation, and thus activation and growth proceeds quickly (Pope, 2010). Some particles of biological origin (e.g., $P$. syringae bacteria and some fungal species) have been found to efficiently nucleate ice growth at relatively high temperatures (Després et al., 2012; Murray et al., 2012; Hoose and Möhler, 2012; Morris et al., 2004, 2013; Haga et al., 2013). Biological particles have been observed ubiquitously in precipitation, fog, and snowpack (e.g., Christner et al., 2008) as well as in clouds by airborne measurements (e.g., Prenni et al., 2009; DeLeonRodriguez et al., 2013), and have been shown to be important fractions of IN measured at ground level (e.g., Huffman et al., 2013; Prenni et al., 2013). These bio-IN may be important for ice nucleation in mixed-phase clouds at temperatures higher than $-15^{\circ} \mathrm{C}$ (DeMott and Prenni, 2010). In regimes colder than that, mineral dust particles and other ice nucleators are also active, and the relative atmospheric abundance of PBAP is probably too small to contribute significantly to formation and evolution of these colder clouds. Previous modeling studies suggest that bio-IN concentrations are several orders of magnitude lower than IN concentrations from mineral dust or soot and hence the influence of bio-IN on precipitation is limited on the global scale (Hoose et al., 2010a; Sesartic et al., 2012; Spracklen and Heald, 2014). In situ analyses of insoluble cloud ice and precipitation residuals meanwhile highlight the contribution of bio-IN to precipitation, and back trajectories indicate that they can be transported over large distances (Creamean et al., 2013).

The methods for identifying and detecting PBAP are challenging and many different PBAP can introduce significant detection biases. Particle diameter often plays heavily into PBAP detection and characterization, and it should be noted that large discrepancies can exist between physical and aerodynamic diameter measurements (Huffman et al., 2010; Reponen et al., 2001). PBAP concentrations can be obtained either by online techniques, in which samples are analyzed by advanced instrumentation in real time, or by offline measurement techniques. If measured offline, samples of airborne biological particles are stored under refrigeration and common methods include analysis by microscopy (stained or unmodified), by cultivation of the sample on growth media, and by amplification and detection of genetic material by sequencing or electrophoretic separation. Chemical and optical properties of PBAP samples or their tracers can be monitored 
in real time by chromatography, mass spectrometry, fluorescence spectrophotometry, lidar, and flow cytometry. Short overviews of PBAP analysis techniques have been given by Caruana (2011) and Després et al. (2012).

This paper focuses on the mesoscale simulation of atmospheric concentrations of fungal spores. A limited-area model is used for the simulations and the setup includes a model domain covering most parts of Europe with a horizontal resolution of $14 \mathrm{~km}$. Two different fungal spore emission parameterizations (Heald and Spracklen, 2009; Sesartic and Dallafior, 2011) are tested by comparing their number concentrations to online laser-induced fluorescence (LIF) measurements of airborne fluorescent biological particles. Additionally, a new emission parameterization adapted to these measurements is introduced. Field data used here come from a real-time measurement technique that detects the intrinsic (i.e., unstained) fluorescence signal, after UV excitation, of fluorophores commonly present in most biological materials (e.g., free proteins. fungal spores, bacteria, and leaf fragments). Detected particles are categorized as fluorescent biological aerosol particles (FBAP), which may broadly be considered a lower limit for the abundance of PBAP (Huffman et al., 2010; Pöhlker et al., 2012; Healy et al., 2014). FBAP were measured at four different locations (Table 1) concurrently during three focus periods in summer 2010 and fall 2010. The resulting FBAP size distribution is usually dominated by particles in the range from 2 to $4 \mu \mathrm{m}$, which is consistent with the size of fungal spores (Huffman et al., 2010, 2012, 2013; Pöschl et al., 2010, Healy et al., 2012a; Toprak and Schnaiter, 2013). Further, the concentration of FBAP in a given air mass is generally considered to underestimate PBAP concentration due to biological particles that exhibit very low levels of fluorescent emission (Huffman et al., 2012). To some extent, non-biological aerosol components can also be part of the fluorescence signal for fine particles $(\sim 1 \mu \mathrm{m})$ (Huffman et al., 2010; Toprak and Schnaiter, 2013). These factors contribute uncertainty to the evaluation of the parameterizations discussed here; however, the overall ability of LIF techniques to provide real-time FBAP measurements allows for first approximation measurements that can be enlightening.

\section{Methodology}

\subsection{Model description}

The COSMO-ART (Consortium for Small-scale ModellingAerosols and Reactive Trace gases) atmospheric model system is based on the forecast model of the German weather service, combined with an online coupled module for simulating the spatial and temporal distribution of reactive gaseous and particulate components (Vogel et al., 2009). Additionally, fungal spores are incorporated as an independent, monodisperse particle class $\left(d_{\mathrm{p}}=3 \mu \mathrm{m}\right)$.
Parameterizations for emission, sedimentation, and washout, which were originally developed for pollen dispersal, are included for this particle class (Helbig et al., 2004). Fungal spores are treated independently, as no interactions with other aerosols or gases (coagulation or condensation) are considered. The temporal development of the fungal spore number concentration is calculated by

$\rho \frac{\mathrm{d} \Psi}{\mathrm{d} t}=-\nabla \cdot \boldsymbol{F}_{\mathrm{T}}-\frac{\partial}{\partial z} F_{\mathrm{S}}-\lambda \Psi-\frac{1}{N} \frac{\partial}{\partial z} F_{\mathrm{E}}$,

where the number mixing ratio of fungal spores being

$\Psi=\frac{N_{\mathrm{f}}}{N}$,

$N_{\mathrm{f}}$ is the number concentration of fungal spores, $N$ per $\mathrm{m}^{3}$ the total number of particles and air molecules, $\rho$ the air density, $\boldsymbol{F}_{\mathrm{T}}$ the turbulent flux, $F_{\mathrm{S}}$ the sedimentation flux, $\lambda$ a washout coefficient, and $F_{\mathrm{E}}$ a vertical emission flux (Vogel et al., 2008). The turbulent flux is calculated by $\boldsymbol{F}_{\mathrm{T}}=\overline{\rho v^{\prime} \Psi^{\prime}}$, incorporating the turbulent fluctuations of wind speed $v^{\prime}$ and fungal spore number mixing ratio $\Psi^{\prime}$. Fungal spore sedimentation is calculated by $F_{\mathrm{S}}=\rho \Psi v_{\mathrm{s}}$. The fungal spore settling velocity $v_{\mathrm{S}}$ is calculated by applying the volume-equivalent particle diameter $d_{\mathrm{e}}=2 \sqrt[3]{a^{2} b}$, with $a=1 \mu \mathrm{m}$ and $b=5 \mu \mathrm{m}$ (Yamamoto et al., 2012) being the major and minor radius of a prolate spheroid. This results in

$v_{\mathrm{s}}^{2}=\frac{4 \rho_{\mathrm{p}} d_{\mathrm{e}} g}{3 \rho c_{\mathrm{d}}}$,

where $\rho_{\mathrm{p}}=1 \mathrm{~g} \mathrm{~cm}^{-3}$ is the spore density (Trail et al., 2005; Gregory, 1961) and $c_{\mathrm{d}}$ the drag coefficient (Aylor, 2002). The calculation of the washout coefficient is based on the assumption of raindrops being much larger than aerosol particles and having a much higher terminal fall velocity. It yields

$\lambda\left(d_{\mathrm{p}}\right)=\int_{0}^{\infty} \frac{\pi}{4} D_{\mathrm{D}}^{2} v_{\mathrm{t}}\left(D_{\mathrm{D}}\right) E\left(d_{\mathrm{p}}, D_{\mathrm{D}}\right) n\left(D_{\mathrm{D}}\right) \mathrm{d} D_{\mathrm{D}}$

(Rinke, 2008). $D_{\mathrm{D}}$ and $d_{\mathrm{p}}$ are the diameters raindrops and of particles, respectively, $v_{\mathrm{t}}\left(D_{\mathrm{D}}\right)$ is the terminal fall velocity, $E$ is a collision efficiency, and $n\left(D_{\mathrm{D}}\right)$ is the size distribution of the raindrop number concentration. For fungal spores with a spherical diameter of $3 \mu \mathrm{m}$, the collision efficiency $E$ with 0.1 and $1 \mathrm{~mm}$ droplets is approximately 0.085 and 0.3 , respectively.

Adapting the model for simulations of fungal spores requires inclusion of an emission flux $F_{\mathrm{E}}$ in the source term of Eq. (1) by means of an emission parameterization which will be described in the next section.

Together with fungal spore simulations, COSMO-ART is used to compute the mass concentration of major atmospheric aerosol components. Hence, the proportion of fungal spores with respect to the dry aerosol mass can be estimated 
Table 1. Overview of the measurement sites, including their geographical location and the types of instrument used ( $d_{\mathrm{p}}$ corresponds to the optical particle diameter and $d_{\mathrm{a}}$ to the aerodynamic particle diameter). The sections below show the simulation periods and the availability of data at this site (filled dot). Mean values for the simulated meteorological and surface conditions used for the new emission parameterization (Sect. 3.2) at the measurement site during the corresponding time periods are added to each section.

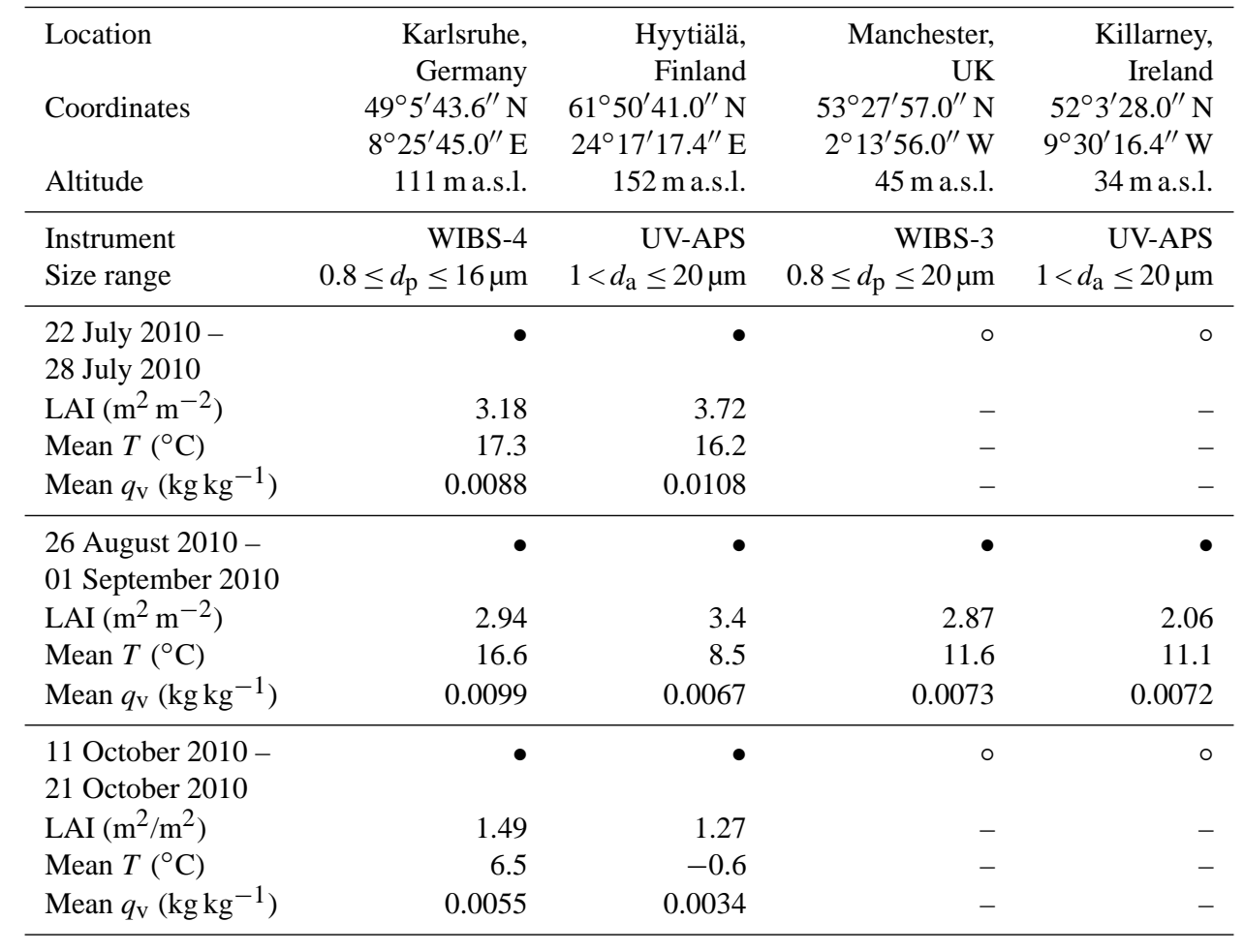

(Sect. 3.4). In addition to primary aerosol emissions, further gaseous emissions (Sect. 2.3) are taken into account. Partitioning of inorganic aerosol components between the gases and particulate phase is simulated by the ISORROPIA II module (Fountoukis and Nenes, 2007). Condensation on fungal spore aerosols is not included. The contribution of secondary organic aerosols (SOA) to the particles is handled by condensation of oxidized volatile organic compounds as described by Schell et al. (2001). When soot aerosols are not involved as a solid nuclei enabling condensation, clusters build by gas-to-particle conversion via binary nucleation of sulfuric acid and water. They are computed as an individual particle mode. All aerosol particles including these chemical compounds are assumed to be internally mixed. A soot mode without mixing of other chemical compounds is included as particles that are emitted directly into the atmosphere. Anthropogenic primary aerosols (aPA) in the coarse size range $(<10 \mu \mathrm{m})$ are treated as a separate mode. Detailed descriptions are given in Vogel et al. (2009). Furthermore, sea salt is included in the model simulation and its emission is related to sea water temperature and wind speed (Lundgren et al., 2013). No desert dust emissions are included, as the model domain does not cover the corresponding emission regions and no transport into the model domain is taken into account.

\subsection{Emission parameterization of fungal spores}

In previous studies, a constant emission rate was used as input of a global chemical transport model to represent the magnitude and range of measured concentrations of mannitol as a molecular tracer for basidiospores (Elbert et al., 2007). Broad geographical differences can be included in the emission flux by distinguishing between ecosystems. While reviewing the measured data available on measured fungal spore concentrations, Sesartic and Dallafior (2011) calculated number fluxes of fungal spore emissions for six different ecosystems (defined by Olson et al., 2001). Four of these emission fluxes were included into COSMO-ART, and coupled to ecosystem definitions by the GLC2000 (Global Landcover 2000 Database) (forest and shrubs) and Ramankutty et al. (2008) (grassland and crops). The sum of these fluxes, as defined by Sesartic and Dallafior (2011), are emitted from the land-area fraction $E_{i}$ of each ecosystem $i\left(\sum_{i}^{n} E_{i}=1\right.$ for $n$ number of ecosystems), and give the total emission flux $F_{\mathrm{E}}=F_{\mathrm{S} \& \mathrm{D}}$ in $\mathrm{m}^{-2} \mathrm{~s}^{-1}$ of Eq. (1) for fungal spores 


$$
\begin{aligned}
F_{\mathrm{S} \& \mathrm{D}} & =214 \mathrm{~m}^{-2} \mathrm{~s}^{-1} E_{\text {forest }}+1203 \mathrm{~m}^{-2} \mathrm{~s}^{-1} E_{\text {shrub }} \\
& +165 \mathrm{~m}^{-2} \mathrm{~s}^{-1} E_{\text {grassland }}+2509 \mathrm{~m}^{-2} \mathrm{~s}^{-1} E_{\text {crop }} .
\end{aligned}
$$

Additionally, a second emission parameterization was tested, which varies as a function of meteorological and surface conditions. Jones and Harrison (2004) reviewed the relations determined when analyzing the observed fungal spore concentrations and atmospheric factors. Seasonal variations can be explained by changes in the leaf area index (LAI). This was verified by correlation to the observed mannitol concentrations. Among the drivers of day-to-day variations, specific humidity $\left(q_{\mathrm{v}}\right)$ correlates best with the mannitol concentrations (Heald and Spracklen, 2009). It was argued that though other atmospheric factors (e.g., temperature) may actually drive the correlation, this does not change correlation results and thus parameterizations can proceed without having information about the root drivers of fungal spore release. The emission rate is linearly scaled with LAI and $q_{\mathrm{v}}$ in order to give global fungal spore concentrations matching the mean mannitol concentrations (Heald and Spracklen, 2009). In order to rescale the emission flux specified in Hoose et al. (2010a) from a spore diameter of $5 \mu \mathrm{m}$ as in Hoose et al. (2010a) to a spore diameter of $3 \mu \mathrm{m}$ as in this study, the prefactor $c$ is set to $c=2315 \mathrm{~m}^{-2} \mathrm{~s}^{-1}$. Based on the emission flux in Eq. (1), this gives an alternative source $F_{\mathrm{E}}=F_{\mathrm{H} \& \mathrm{~S}}$ of fungal spores in $\mathrm{m}^{-2} \mathrm{~s}^{-1}$ :

$F_{\mathrm{H} \& \mathrm{~S}}=c \frac{\mathrm{LAI}}{5 \mathrm{~m}^{2} \mathrm{~m}^{-2}} \frac{q_{\mathrm{v}}}{1.5 \times 10^{-2} \mathrm{~kg} \mathrm{~kg}^{-1}}$.

LAI is the leaf area index, and $q_{\mathrm{v}}$ is the specific humidity at the surface. In the COSMO-ART simulations LAI is horizontally distributed according to GLC2000 containing monthly variation, and $q_{\mathrm{v}}$ is provided by the model as a meteorological variable.

\subsection{Model domain and input data}

The COSMO-ART mesoscale model system is driven by initial and boundary data for meteorological conditions. They are updated every $6 \mathrm{~h}$ and result from interpolation of the coarse grid operational atmospheric model analysis of the ECMWF (European Centre for Medium-Range Weather Forecasts). No initial and boundary concentrations are predefined for aerosols or gases. Therefore, all gaseous species are set to a climatological, homogeneously distributed initial concentration and emission rates for chemical compounds included in the ART part are updated hourly. They are provided by EMPA (Swiss Federal Laboratories for Materials Science and Technology) based on the TNO (ToegepastNatuurwetenschappelijk Onderzoek - applied scientific research)/MACC (Monitoring Atmospheric Composition and Climate) inventory (Kuenen et al., 2011). The treatment of emissions for COSMO-ART can be found in Knote et al. (2011). Homogeneously distributed mass densities for each aerosol are used as initial conditions, together with the aerosol size distribution and particle density. Primary particle emissions are included as parameterizations based on meteorological and surface conditions. Land use data and constant surface properties are derived from the GLC2000 database (Bartholomé and Belward, 2005). All parameters are post-processed to the rotated spherical coordinate system of COSMO-ART (Doms and Schättler, 2002). For the purpose of this paper, the model domain covers most parts of western Europe from mainland Portugal to northern Finland, the longitudinal extension being $2849 \mathrm{~km}$ the latitudinal extension being $3803 \mathrm{~km}$ with a horizontal spacing of $0.125^{\circ}$ ( $\widehat{=} 14 \mathrm{~km}$ ) on a rotated grid. In vertical direction the model reaches up to an altitude of about $24 \mathrm{~km}$ distributed over 40 terrain-following levels. The time stepping of the RungeKutta dynamical core is set to $30 \mathrm{~s}$.

\subsection{Auto-fluorescence measurements}

Ambient aerosols can be roughly classified as biological or not by interrogating particles at characteristic wavelengths of excitation and measuring the resultant emission in a process called ultraviolet light-induced fluorescence (UV-LIF) (e.g., Hairston et al., 1997; Pan et al., 1999). In particular, the region of fluorescent excitation near $360 \mathrm{~nm}$ is often used as characteristic of certain cell metabolites present in all living cells, including riboflavin and reduced pyridine nucleotides (e.g., NAD $(\mathrm{P}) \mathrm{H})$. The region of excitation near $270 \mathrm{~nm}$ includes certain amino acids (e.g., tryptophan) contained in most proteins. However, many other biological fluorophores exist and the relationship between the measured fluorescence of complex biological particles and fluorophore assignment is very complex (Pöhlker et al., 2012, 2013).

Two instrument types were utilized at four locations for the comparison discussed in this paper. The ultraviolet aerodynamic particle sizer (UV-APS; TSI, Inc., Shoreview, MN, USA) measures particle size aerodynamically, excites individual particles using a single Nd:YAG laser pulse at $355 \mathrm{~nm}$, and detects integrated fluorescent emission (non-dispersed) in a single wavelength region between 420 and $575 \mathrm{~nm}$ (Hairston et al., 1997; Brosseau et al., 2000; Huffman et al., 2010). The Waveband Integrated Bioaerosol Sensor (WIBS, versions 3 and 4; University of Hertfordshire, UK) measures particle size optically and excites individual particles via two sequential pulses from a Xe-flash lamp, at 280 and $370 \mathrm{~nm}$ (e.g., Kaye et al., 2005; Foot et al., 2008). Fluorescence for each particle is then measured in one of two wavelength regions, resulting in three measured fluorescence parameters for each WIBS instrument named FL1_280, FL2_280, and FL3_370; see Gabey et al. (2010) and Robinson et al. (2013) for more details, including slight differences in WIBS-3 and WIBS-4 models. The number concentration of FBAP can be written as $N_{\mathrm{F}, \mathrm{c}}$ with subscripts referring to fluorescent and coarse particle size. The differences in the pairs of wave- 
lengths used for fluorescence, as well as the possible differences in sensitivity between instruments, suggest that the term "FBAP" as determined by each instrument is not rigorously interchangeable, and it is critical to understand the method of analysis when comparing data sets. For example, the ambient FBAP number concentration as determined by UV-APS has been shown to be qualitatively consistent with the number concentration of particles that fluorescence in the WIBS FL3_370 channel, while the $N_{\mathrm{F}, \mathrm{c}}$ comparison between UV-APS and WIBS FL1_280 channel is relatively poor (Healy et al., 2014). Here we use the term FBAP from WIBS data to mean particles that exhibit fluorescence simultaneously in both channels FL1_280 and FL3_370.

Particle size can aide differentiation between biological particles classes observed; however, the selectivity based on size alone is very uncertain. For example, and to a rough first approximation, it may be true that many FBAP $\sim 1 \mu \mathrm{m}$ are single bacterial particles and that many FBAP $2-6 \mu \mathrm{m}$ may be fungal spores or bacterial agglomerates (Shaffer and Lighthart, 1997). A comparison between WIBS-4 and a Burkard volumetric impactor reported by O'Connor et al. (2014) from a yew forest site showed excellent correlation with $R^{2}>0.9$ demonstrating the real-time counting capability of WIBS for pollen. However, biological species can vary widely, and other FBAP classes (e.g., fragments of larger PBAP, internal components of burst pollen, the presence of other biological species) confound the simple assignment of FBAP based on size (Després et al., 2012).

Further, at least a fraction of fluorescent, supermicron particles are likely to come from non-biological sources, and thus could be counted as FBAP. These non-biological process include particles from anthropogenic sources (e.g., polycyclic aromatic hydrocarbon particles from combustion and cigarette smoke), that are present most often in submicron aerosols (Huffman et al., 2010), select oxidized organic aerosol particles (e.g., absorbing brown carbon particles) (Bones et al., 2010; Lee et al., 2013), and some humiclike substances (Gabey et al., 2013). For example, at the rural, elevated site of Puy de Dôme, France, WIBS-3 FBAP measurements were compared to results from fluorescence microscopy paired with staining of fungal spores and bacteria. These results suggest that the real-time UV-LIF measurements indeed track the diurnal cycle of the bacteria concentration, but that non-biological particles still contributed significantly to the fluorescent particle numbers (Gabey et al., 2013).

Virtually every ambient measurement study performed with the WIBS or UV-APS to date has shown a dominant FBAP mode peaking at $2-4 \mu \mathrm{m}$ in size (Huffman et al., 2010, 2012, 2013; Gabey et al., 2010; Toprak and Schnaiter, 2013; Healy et al., 2014). For example, the FBAP size distributions measured at each of the four sampling locations discussed here is shown in Fig. 1, highlighting the common presence of the $2-4 \mu \mathrm{m}$ peak. It has been proposed that fungal spores and bacteria agglomerates are the most dominant biological

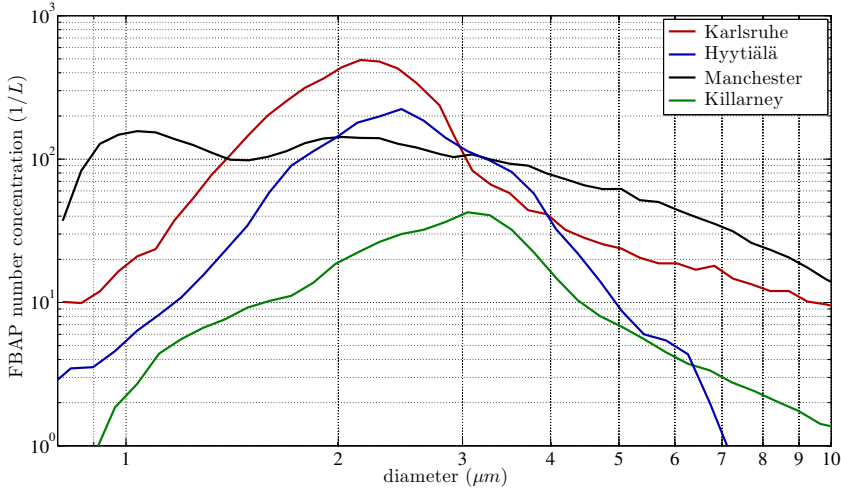

Figure 1. Average FBAP size distributions derived from UVLIF measurements during case studies in August 2010 at Karlsruhe (Germany) with WIBS-4, Hyytiälä (Finland) with UV-APS, Manchester (UK) with WIBS-3, and Killarney (Ireland) with UVAPS.

aerosols in this size range (Jones and Harrison, 2004; Després et al., 2012; Fang et al., 2008) and that the FBAP signal in this size range is typically dominated by fungal spores. This was corroborated in more detail for a remote Amazonian site using FBAP analysis along with fluorescence microscopy of stained filter samples (Huffman et al., 2012), but has not yet been rigorously tested in other environments. At the costal site of Killarney, results of fluorescence and optical microscopy of impacted biological particles reveal that some PBAP, e.g., spores of Cladosporium spp., which have been frequently observed in many environments, were not correlated to the FBAP concentration (Healy et al., 2014). However, particle size modes of WIBS channel FL2_280 correlate with the concentration of airborne fungal spores commonly observed at the sampling site (Healy et al., 2014). Other microscopy and DNA-based studies have suggested that fungal spores constitute the largest fraction of PBAP in the $2-4 \mu \mathrm{m}$ size (e.g., Graham et al., 2003; Lin and Li, 1996; Burch and Levetin, 2002). Bauer et al. (2008) showed that fungal spores account for an average of $60 \%$ of the organic content in the particulate matter in a size range of $2-10 \mu \mathrm{m}$ in rural and urban areas of Vienna, Austria.

\section{Results}

\subsection{Comparison of time series of measured FBAP and simulated fungal spores}

Fungal spore concentrations simulated using the emission fluxes given in Eqs. (5) and (6) according to Sesartic and Dallafior (2011) and Heald and Spracklen (2009) were first compared to FBAP measurements without further adjustment. An overview of time series for all measurements and simulations discussed here is shown in Fig. 2 by a box-and-whiskers plot. Statistical parameters of the correlation between obser- 
Table 2. Correlation coefficient $(R)$, root mean square error (RMSE), and normalized mean bias (NMB) for correlations between simulated fungal spore/FBAP and measured FBAP concentrations at different locations and three different time periods.

\begin{tabular}{|c|c|c|c|c|c|c|c|c|c|c|c|}
\hline & \multicolumn{3}{|c|}{$N_{\mathrm{H} \& \mathrm{~S}}$} & \multicolumn{3}{|c|}{$N_{\mathrm{S} \& \mathrm{D}}$} & \multicolumn{3}{|c|}{$N_{\text {FBAP }}$} & \multicolumn{2}{|c|}{$\begin{array}{c}\text { Confidence } \\
\text { intervals for } R\end{array}$} \\
\hline & $R$ & $\begin{array}{r}\text { RMSE } \\
{\left[\mathrm{L}^{-1}\right]}\end{array}$ & $\begin{array}{r}\mathrm{NMB} \\
{[\%]}\end{array}$ & $R$ & $\begin{array}{r}\text { RMSE } \\
{\left[\mathrm{L}^{-1}\right]}\end{array}$ & $\begin{array}{r}\mathrm{NMB} \\
{[\%]}\end{array}$ & $R$ & $\begin{array}{r}\text { RMSE } \\
{\left[\mathrm{L}^{-1}\right]}\end{array}$ & $\begin{array}{r}\mathrm{NMB} \\
{[\%]}\end{array}$ & $95 \%$ & $99 \%$ \\
\hline Karlsruhe, Jul 2010 & 0.07 & 45 & -58 & 0.11 & 48 & -66 & 0.07 & 38 & -32 & \pm 0.17 & \pm 0.22 \\
\hline Karlsruhe, Aug 2010 & 0.11 & 25 & -36 & -0.07 & 28 & -40 & 0.11 & 30 & 1.4 & \pm 0.16 & \pm 0.20 \\
\hline Karlsruhe, Oct 2010 & -0.11 & 22 & -64 & 0.01 & 21 & 20 & -0.17 & 17 & -35 & \pm 0.18 & \pm 0.23 \\
\hline Hyytiälä, Jul 2010 & 0.57 & 17 & 3.2 & 0.58 & 24 & -67 & 0.57 & 23 & 51 & \pm 0.11 & \pm 0.15 \\
\hline Hyytiälä, Aug 2010 & 0.04 & 20 & -62 & 0.19 & 22 & -76 & 0.00 & 18 & -46 & \pm 0.16 & \pm 0.21 \\
\hline Hyytiälä, Oct 2010 & 0.01 & 4.7 & -58 & -0.10 & 5.1 & 35 & 0.23 & 4.6 & -59 & \pm 0.17 & \pm 0.23 \\
\hline Manchester, Aug 2010 & 0.68 & 15 & 2.7 & 0.65 & 19 & 38 & 0.66 & 22 & 63 & \pm 0.09 & \pm 0.12 \\
\hline Killarney, Aug 2010 & 0.49 & 6.6 & 84 & 0.32 & 15 & 200 & 0.45 & 15 & 214 & \pm 0.13 & \pm 0.17 \\
\hline All & 0.428 & 26.2 & -44.04 & -0.05 & 25.6 & -28.74 & 0.433 & 23.2 & -0.43 & \pm 0.05 & \pm 0.06 \\
\hline
\end{tabular}

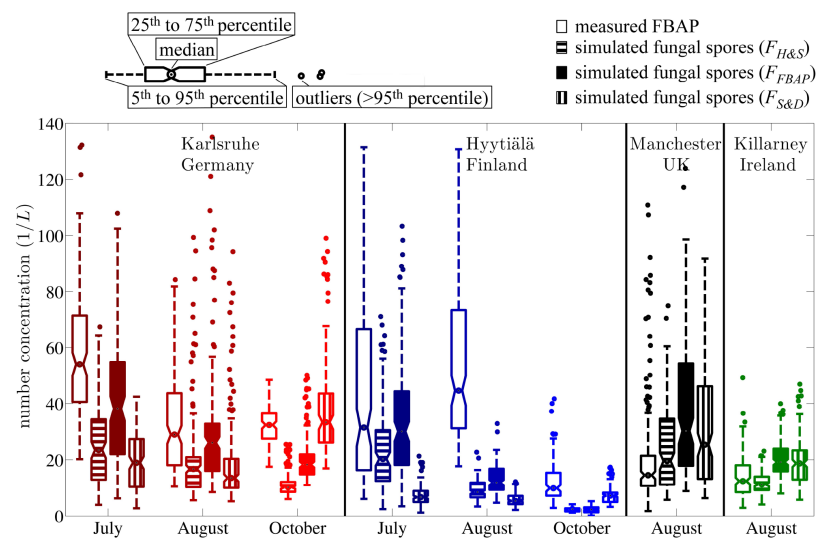

Figure 2. Box-whisker plots for all case studies of measured hourly FBAP concentration (open boxes), simulated fungal spore concentration with three different emission parameterizations: $F_{\mathrm{H} \& \mathrm{~S}}$ from Heald and Spracklen (2009; horizontally hatched boxes), $F_{\text {FBAP }}$ from this study (filled boxes), and $F_{\mathrm{S} \& \mathrm{D}}$ from Sesartic and Dallafior (2011; vertically hatched boxes). The central mark of each box shows the median, its edges the 25 th and 75 th percentiles, and whiskers show 5th and 95th percentiles. Dots above whisker show outliers (>95th percentile).

vations and simulations are presented in Table 2 . The time periods for each of three case studies (Table 1) were chosen as exemplary periods when UV LIF instruments were operating simultaneously at a minimum of two locations, with no requirements applied with respect to environmental conditions. For the statistical analysis, FBAP measurements were averaged over $1 \mathrm{~h}$ periods in order to be consistent to the model output time steps. The correlation coefficient for the entire data set amounts to $R=0.43$ for the simulation with the (Heald and Spracklen, 2009) emission $\left(F_{\mathrm{H} \& \mathrm{~S}}\right)$ and to $R=0.05$ for the simulation with the (Sesartic and Dallafior, 2011) $\left(F_{\mathrm{S} \& D}\right)$ parameterization. For most time periods at Karlsruhe and Hyytiälä, the simulated fungal spore concentrations are smaller than the measured FBAP concentrations (Fig. 2). This difference is the highest at Hyytiälä in August 2010. At Hyytiälä in July and at Manchester and Killarney in August, $F_{\mathrm{H} \& \mathrm{~S}}$ gives median concentration values which agree reasonably well with the measurements. During October, the fungal spores number concentrations based on constant emission fluxes $\left(F_{\mathrm{S} \& \mathrm{D}}\right)$ agree best with the measured FBAP concentrations. Taking the whole data set together, these deviations result in negative values of the normalized mean bias (NMB) of $44 \%$ for $F_{\mathrm{H} \& \mathrm{~S}}$ and of $-29 \%$ for $F_{\mathrm{S} \& \mathrm{D}}$ and root mean square errors (RMSEs) of 26.2 and $25.6 \mathrm{~L}^{-1}$, respectively (Table 2). Possible causes for the bias of $F_{\mathrm{H} \& \mathrm{~S}}$ and $F_{\mathrm{S} \& \mathrm{D}}$ may come from different assumptions made to determine the fungal spore concentrations in ambient air. On the one hand, the mass size distribution of mannitol, which is used as a chemical tracer for fungal spores by Heald and Spracklen (2009), peaks in their study at particle diameters of $\sim 5 \mu \mathrm{m}$. In addition to fungal spores, bacteria, algae, lichens, and plant fragments can produce mannitol and some of these can contribute to PBAP concentrations at $\sim 5 \mu \mathrm{m}$. On the other hand, similar assumptions are made for this study by linking FBAP to fungal spores, which can also introduce biases. Furthermore, the treatment of fungal spores as monodisperse particles in the model (while the observed size distribution is rather broad) influences the simulated removal processes and thus the resulting concentrations.

Long-term analysis of FBAP measurements, including periods at the Karlsruhe (Toprak and Schnaiter, 2013) and Hyytiälä site (Schumacher et al., 2013) discussed here, shows an annual cycle of average FBAP number concentrations peaking in summer and lowest in winter. Thus, a simulation based on a constant emission flux (such as $F_{\mathrm{S} \& \mathrm{D}}$ ) may not be appropriate to reproduce the seasonal variation in FBAP concentrations, contributing to the low value of $R$. 


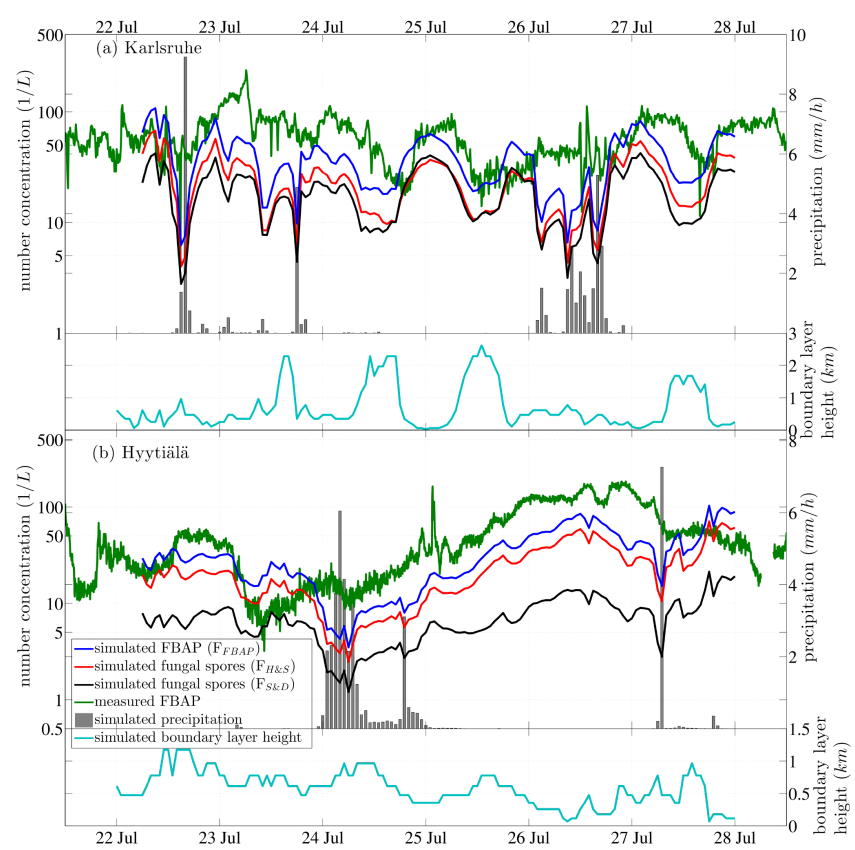

Figure 3. Time series of measured FBAP and simulated fungal spore/FBAP number concentrations in $1 \mathrm{~L}^{-1}$ together with simulated precipitation in $\mathrm{mm} \mathrm{h}^{-1}$ (right axis) and simulated boundary layer height in kilometers (right axis) during the case study from 22 July to 28 July 2010 at (a) Karlsruhe, Germany, and (b) Hyytiälä, Finland. Simulations were performed with three different emission parameterizations: $F_{\mathrm{H} \& S}$ from Heald and Spracklen (2009), $F_{\mathrm{S} \& \mathrm{D}}$ from Sesartic and Dallafior (2011), and $F_{\mathrm{FBAP}}$ from this study.

Figures 3 to 6 show a series of 1-week-long case studies, each representing two measurement sites. The plots show comparisons between simulation and measurement time series for each station. The simulated fungal spore number concentration is given for the model grid point closest to the measuring site. Due to model spin-up, the first $6 \mathrm{~h}$ of the simulated fungal spore concentrations are removed from the figures and are not included in the analysis. The total precipitation calculated by the model is shown by gray bars with the ordinate on the right-hand side of the figure. The simulated boundary layer height is also included at the bottom of each panel in the figures.

Measured FBAP number concentrations often exhibit distinct diel $(24 \mathrm{~h})$ cycles with a maximum in the morning hours or around midnight and a minimum around noon. These features have been consistently reported by most studies discussing temporal behavior of FBAP (Gabey et al., 2010; Huffman et al., 2010, 2012; Toprak and Schnaiter, 2013). Here, a similar diel cycle is frequently obtained from simulations, and the simulated fungal spore concentrations often anti-correlate with the simulated boundary layer height $\left(h_{\mathrm{PBL}}\right)$ (Figs. 3 to 6$)$. The measured FBAP concentrations often qualitatively track the general pattern of simulated $h_{\mathrm{PBL}}$; however, the magnitude of concentration change and the tim-

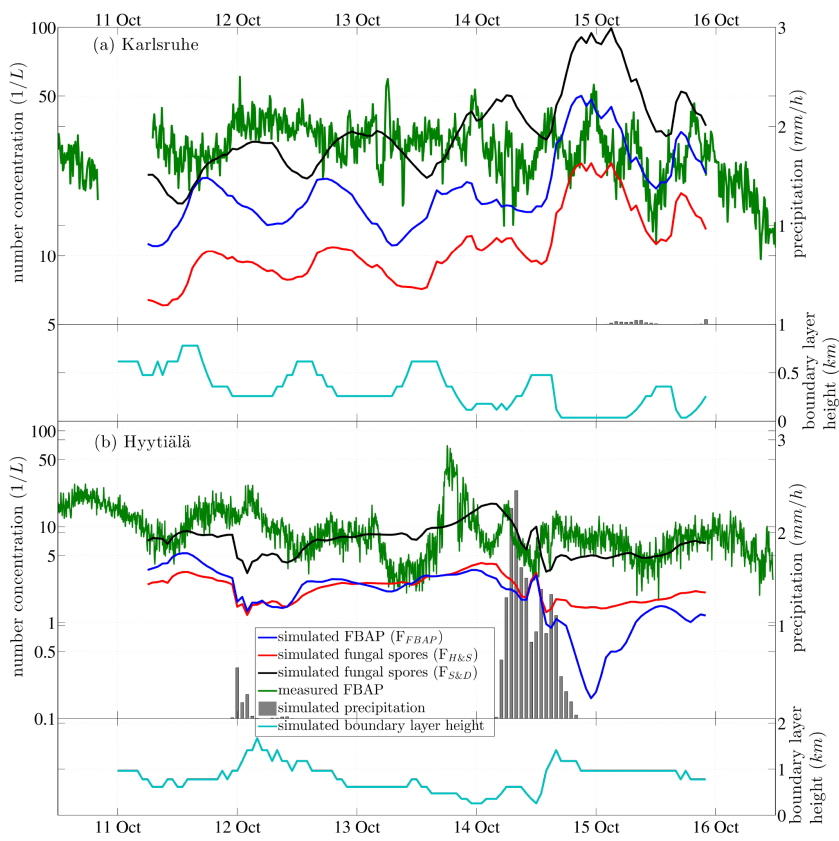

Figure 4. Time series of measured FBAP and simulated fungal spore/FBAP number concentrations in $1 \mathrm{~L}^{-1}$ together with simulated precipitation in $\mathrm{mm} \mathrm{h}^{-1}$ (right axis) and simulated boundary layer height in kilometers (right axis) during the case study from 11 October 2010 to 21 October 2010 at (a) Karlsruhe, Germany, and (b) Hyytiälä, Finland. Simulations were performed with three different emission parameterizations: $F_{\mathrm{H} \& \mathrm{~S}}$ from Heald and Spracklen (2009), $F_{\text {S\&D }}$ from Sesartic and Dallafior (2011), and $F_{\text {FBAP from this study. }}$

ing is often not consistent. For example, on 24 and 25 July at the Karlsruhe site (Fig. 3a) a boundary layer compression during the night leads to an increase in the simulated fungal spore concentrations by a factor of $\sim 4$, and during day the concentrations decreases as the boundary layer rises again. In this case, the measured FBAP concentrations are in relatively good agreement with the simulated fungal spore numbers, with $N_{\mathrm{F}, \mathrm{c}}$ dropping slowly during the day on 24 and $27 \mathrm{July}$, and to a rate closer to the simulations on $25 \mathrm{July}$. This suggests that FBAP concentrations were likely influenced, at least partially, by the changing boundary layer height, though diel changes in biological emission are also likely to influence diel FBAP patterns. A similar temporal pattern in simulated fungal spore concentrations is shown in Fig. 4a, where a maximum in $h_{\mathrm{PBL}}$ at 12 and 13 October occurs approximately coincident with a minimum in the simulated number concentration. In this case, however, the measured FBAP concentrations do not reflect the diel pattern of the simulations. On 31 August (Fig. 5a), measured FBAP and simulated fungal spore number concentration increase simultaneously and parallel to the boundary layer compression, but the increase is more intense for FBAP measurements than for spore simulations. Additionally, at Manchester between 


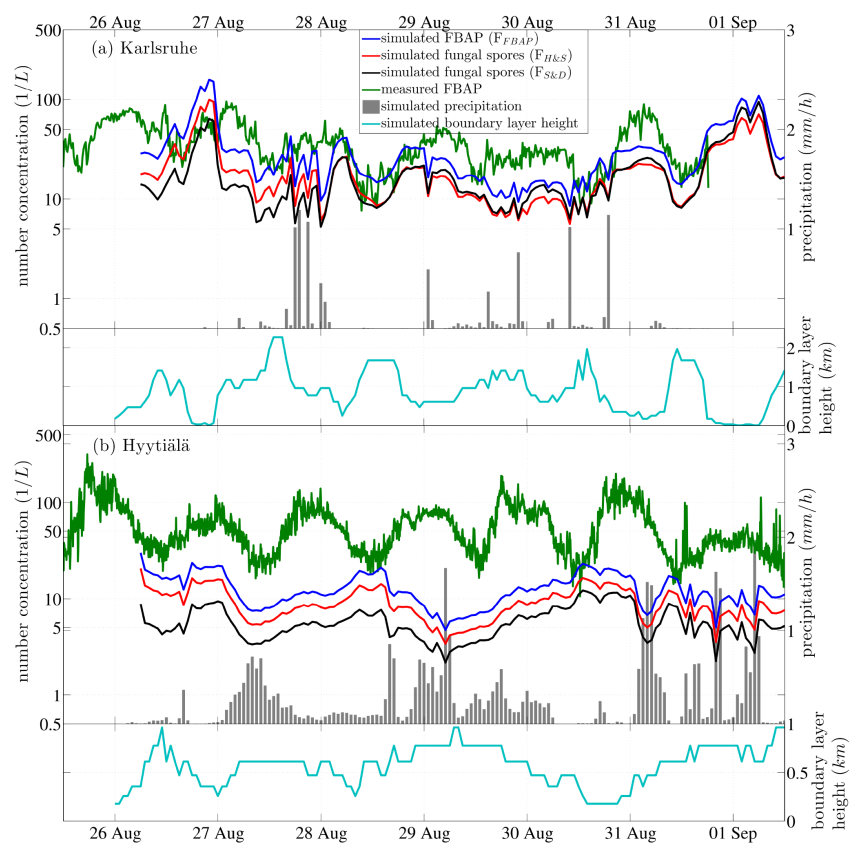

Figure 5. Time series of measured FBAP and simulated fungal spore/FBAP number concentrations in $1 \mathrm{~L}^{-1}$ together with simulated precipitation in $\mathrm{mm} \mathrm{h}^{-1}$ (right axis) and simulated boundary layer height in kilometers (right axis) during the case study from 26 August 2010 to 1 September 2010 at (a) Karlsruhe, Germany; (b) Hyytiälä, Finland. Simulations were performed with three different emission parameterizations: $F_{\mathrm{H} \& \mathrm{~S}}$ from Heald and Spracklen (2009), $F_{\mathrm{S} \& D}$ from Sesartic and Dallafior (2011), and

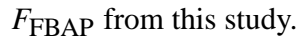

31 August and 1 September (Fig. 6a), measured and simulated concentrations are in good agreement. Distinct minima and maxima clearly anti-correlate with the minima and maxima of the boundary layer height. Similarly, during the same time period in Killarney (Fig. 6b), changes in the boundary layer height were simulated along with coincident changes in fungal spore concentrations. In contrast, Figs. $4 \mathrm{a}$, b, and $5 \mathrm{~b}$ show diel FBAP concentration changes that correlate poorly with simulated $h_{\mathrm{PBL}}^{-1}$.

For a more quantitative analysis, the correlation coefficient between $N_{\mathrm{f}}$ and $h_{\mathrm{PBL}}^{-1}$ was calculated for the whole data set (Table 3). The resulting value is a small positive correlation of $R=0.11$ with a $95 \%$ confidence interval between 0.05 and 0.17 . If all data points with simulated boundary layer heights below $10 \mathrm{~m}$ (which are considered problematic as the vertical resolution of the model is coarser than $10 \mathrm{~m}$ ) are omitted from the correlation analysis, the correlation coefficient rises to $R=0.18$ with a $95 \%$ confidence interval between 0.12 and 0.24 . The correlation coefficients for the individual time series are also listed in Table 3. Note that a large positive correlation cannot be expected, as variations in the emission flux, deposition processes, and transport all lead to a reduction of the correlation between and $h_{\mathrm{PBL}}^{-1}$. Three of

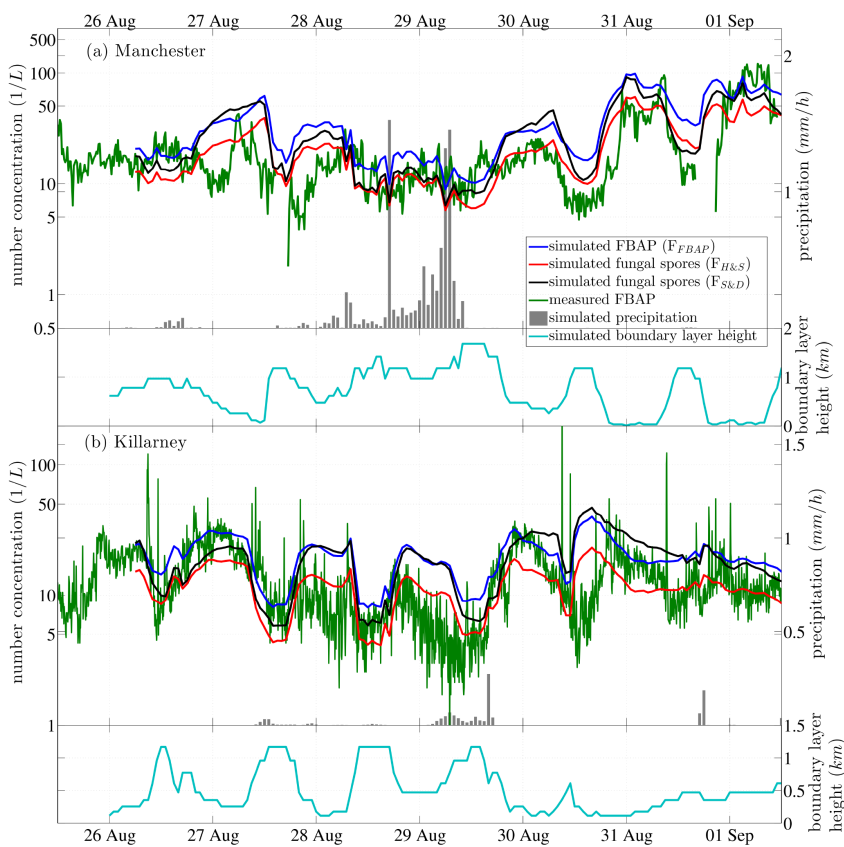

Figure 6. Time series of measured FBAP and simulated fungal spore number/FBAP concentrations in $1 \mathrm{~L}^{-1}$ together with simulated precipitation in $\mathrm{mm} \mathrm{h}^{-1}$ (right axis) and simulated boundary layer height in kilometers (right axis) during the case study from 26 August 2010 to 1 September 2010 at (a) Manchester, UK, and (b) Killarney, Ireland. Simulations were performed with three different emission parameterizations: $F_{\mathrm{H} \& \mathrm{~S}}$ from Heald and Spracklen (2009); $F_{\text {S\&D }}$ from Sesartic and Dallafior (2011); $F_{\text {FBAP }}$ from this study.

Table 3. Correlation coefficient $(R)$ and confidence intervals for correlations between observed FBAP concentrations and the inverse boundary layer height at different locations and three different time periods.

\begin{tabular}{lrrr}
\hline & $R$ & $\begin{array}{r}95 \% \\
\text { confidence } \\
\text { interval }\end{array}$ & $\begin{array}{r}99 \% \\
\text { confidence } \\
\text { interval }\end{array}$ \\
\hline Karlsruhe, Jul 2010 & 0.11 & \pm 0.16 & \pm 0.21 \\
Karlsruhe, Aug 2010 & -0.03 & \pm 0.16 & \pm 0.21 \\
Karlsruhe, Oct 2010 & -0.12 & \pm 0.15 & \pm 0.19 \\
Hyytiälä, Jul 2010 & 0.35 & \pm 0.15 & \pm 0.19 \\
Hyytiälä, Aug 2010 & 0.32 & \pm 0.14 & \pm 0.18 \\
Hyytiälä, Oct 2010 & -0.20 & \pm 0.18 & \pm 0.23 \\
Manchester, Aug 2010 & 0.52 & \pm 0.12 & \pm 0.15 \\
Killarney, Aug 2010 & 0.29 & \pm 0.14 & \pm 0.19 \\
\hline All & 0.11 & \pm 0.06 & \pm 0.07 \\
All, without h < 10 m & 0.18 & \pm 0.06 & \pm 0.07 \\
\hline
\end{tabular}

the stations exhibit negative correlation coefficients, which might be due to perturbations by rain as discussed below.

We conclude that (i) simulated fungal spore concentrations are sensitive to changes in the simulated boundary layer 
height, by extension, that (ii) diel cycles of FBAP concentrations are likely to be partially influenced by diel cycles of boundary layer height, but that (iii) the development of the FBAP concentration is in addition influenced by daily cycles in biological emission processes, including those of fungal spores and other PBAP classes, and atmospheric transport and sink processes. These competing effects are difficult to separate when only point measurements are available.

A comparison of measured FBAP and simulated fungal spore number concentrations for July 2010 is shown in Fig. 3. At the measurement site of Karlsruhe, diel cycles were found in the simulated and measured time series, with constantly lower concentrations being obtained from simulations based on emission parameterizations given in literature. When precipitation occurs in the simulation, the simulated fungal spore concentrations decrease due to washout and the diel development of the concentration is interrupted. Afterwards, the simulated concentrations quickly return to the previous baseline. At Hyytiälä a strong decrease in simulated fungal spore concentration on 24 July precisely overlaps with the simulation of precipitation. After hitting a minimum value during simulated precipitation, the simulated fungal spore concentration increases steadily for 2 days as a result of a post-frontal shift in wind direction and decrease in wind speed. The increase is also reflected in the measured FBAP concentrations. However, the simulated precipitation values do not always coincide with precipitation at the site, as was the case in this instance. As a result of no rain falling at the site on 24 July, the measured FBAP concentration was not affected by washout as in the simulations. This example shows that errors in the simulated meteorology contribute to uncertainty in the simulated aerosol concentrations. Additionally, other dynamic processes are known to affect FBAP concentrations. For example, FBAP have been shown to increase dramatically during rainfall, a process reported recently for both a site in Colorado (Huffman et al., 2013) and also at the Hyytiälä site (Schumacher et al., 2013). The reasons for this FBAP increase are unclear, but are thought to be related to mechanical ejection from terrestrial surfaces as a result of rain droplet splash (Huffman et al., 2013). These effects are known to be dependent on the local geography and ecology, however, and are outside the scope of the presented emission parameterizations.

During the simulation period of October 2010, the simulated fungal spore number concentrations $F_{\mathrm{H} \& \mathrm{~S}}$ are consistently below the measured FBAP concentrations at the sites of Karlsruhe and Hyytiälä, whereas $F_{\mathrm{S} \& \mathrm{D}}$ matches the relative magnitude of the measurements more closely in both cases (Fig. 4). At Karlsruhe, concentrations simulated by each emission parameterization follow a distinct diel cycle and increase slightly through the week, reaching concentration maxima on 15 October. The measured FBAP concentration develops differently, with only a very weak diel cycle present from 11 to 14 October, and showing little relationship to the simulated $h_{\mathrm{PBL}}$, as discussed above.
At the end of August 2010, four different measurement series were available for a comparison to fungal spore simulations (Figs. 5 and 6). The measured time series of FBAP number concentrations generally exhibit diel cycles, as discussed. The absolute FBAP concentration at Hyytiälä was consistently the highest, when comparing all four sites. This trend is even more obvious when comparing the median concentrations on a linear scale (Fig. 2). Concentrations simulated from the literature-based parameterizations underpredict measurements by the greatest margin at Hyytiälä. This underprediction is likely a result of particle washout due to the persistent precipitation simulated by the model and is an indication that precipitation has a stronger influence on the simulated concentrations than changes in the boundary layer height. Measured rainfall during this period at Hyytiälä was less continuous than the model predicts, but occurred with episodic peaks. In all other August case studies, simulated fungal spore concentrations show relatively good agreement with FBAP measurements.

\subsection{Development of a new FBAP emission parameterization by adaptation to FBAP measurements}

Direct comparison between simulated fungal spores and measured FBAP reveals that in general the simulated concentrations are lower than the measured concentrations (Fig. 8a). This difference is most distinct at Hyytiälä during the $\mathrm{Au}$ gust case study and at Karlsruhe in the July and October case studies. Here we suggest a new parameterization, including meteorological and surface parameters identified earlier, as drivers of emissions of FBAP, which may in many cases be comparable to fungal spores. In the model, FBAP are treated identically to fungal spores as described in Sect. 2.1. Additionally, new parameters driving FBAP emissions have been investigated. The emission flux depends on these parameters and their fitting coefficients obtained from a regression analysis of the FBAP measurements as described below. The new parameterization for FBAP emissions has been incorporated into COSMO-ART and the resulting concentrations are included in Figs. 3 to 6.

The adjusted parameterization for the emission flux is based on a regression analysis of an emission flux $F_{\mathrm{F}, \mathrm{c}}$ estimated from the FBAP number concentration. For this, it is assumed that particles are evenly distributed throughout the planetary boundary layer and that the simulated FBAP concentration correlates with $h_{\mathrm{PBL}}^{-1}$. This assumption is expected to be fulfilled best for days with a cloud-free convective boundary layer. Together with a steady-state condition and neglecting horizontal exchanges with the surrounding air, the balance holds between the number concentration $\left(N_{\mathrm{f}}\right)$ and the emission rate $\left(F_{\mathrm{F}, \mathrm{c}}\right)$ together with the atmospheric lifetime of $\operatorname{FBAP}(\tau)$ :

$N_{\mathrm{f}}=\frac{F_{\mathrm{F}, \mathrm{c}} \tau}{h_{\mathrm{PBL}}}$ 
(Seinfeld and Pandis, 2006). The boundary layer height at the measurement site needs to be taken from the model simulation as it is not measured consistently. Equation (7) is applicable to derive estimates for $F_{\mathrm{F}, \mathrm{c}}$ under the assumption that the variation of the simulated boundary layer height explains a significant amount of the variation in $N_{\mathrm{f}}$. This condition is fulfilled for four of the individual time series and to a lesser extent for the data set as a whole (see Sect. 3.1 and Table 3).

In Eq. (7), the FBAP lifetime represents a boundary layer residence time. For an initial test simulation, $\tau$ was assumed to be constant and estimated with an initial value of 1 day, as given in literature for atmospheric lifetimes of aerosol particles with $3 \mu \mathrm{m}$ in diameter (Jaenicke, 1978). In this test simulation, the resulting FBAP concentrations were a about factor of 5 lower compared to the FBAP measurements. As a remedy, $\tau$ is heuristically adjusted to $\tau=4 \frac{3}{4} \mathrm{~h}$, such that the simulated concentrations on average match the observed concentrations. The deviation from a lifetime of $3 \mu \mathrm{m}$ particles given in literature may be attributed to different factors, like the vertical variation of the concentration of fungal spores within the boundary layer (example shown in Fig. 7), the broad size distribution of FBAP particles (see Fig. 1), advection processes, non-equilibrium conditions, and the exchange with the free troposphere and the much longer lifetime of spores above the boundary layer.

Two types of instruments operating with different numbers of channels and detecting fluorescence at different wavelengths are used here for deriving an emission parameterization appropriate for fungal spores. The technical difference may lead to significantly different FBAP concentrations (Healy et al., 2014), because the WIBS instrument only counts particles as FBAP when a signal exceeds a threshold in both channels (Pöhlker et al., 2012; Gabey et al., 2010). Some fungal spores most abundant in the Earth's atmosphere and very common for fungal spores of 2-4 $\mu \mathrm{m}$ (Cladosporium sp., Aspergillus versicolor, Penicillium solitum) (Fröhlich-Nowoisky et al., 2012; Hameed and Khodr, 2001) only show a weak signal in the emission wavelength of 310 to $400 \mathrm{~nm}$ (Saari et al., 2013; Healy et al., 2014). This difference needs to be taken into account when comparing absolute concentrations of fungal spores and FBAP. During the time periods shown here, the WIBS indicate slightly lower FBAP concentrations than the UV-APS when comparing to the model results. In general, this feature is not always valid and detailed side-by-side comparisons between the two types of instruments are required to determine their behavior in terms of FBAP detection and estimation of the PBAP concentration. In the attempt to factor out the technical difference between the instruments, we assume that the FBAP concentration can be multiplied by a constant factor for the concentration values to match each other. The amount of FBAP given by the UV-APS may be represented best by WIBS channel FL3_370 (Sect. 2.4). The FBAP concentration given by the UV-APS is therefore reduced by a factor derived from the WIBS instrument as the mean ratio be-

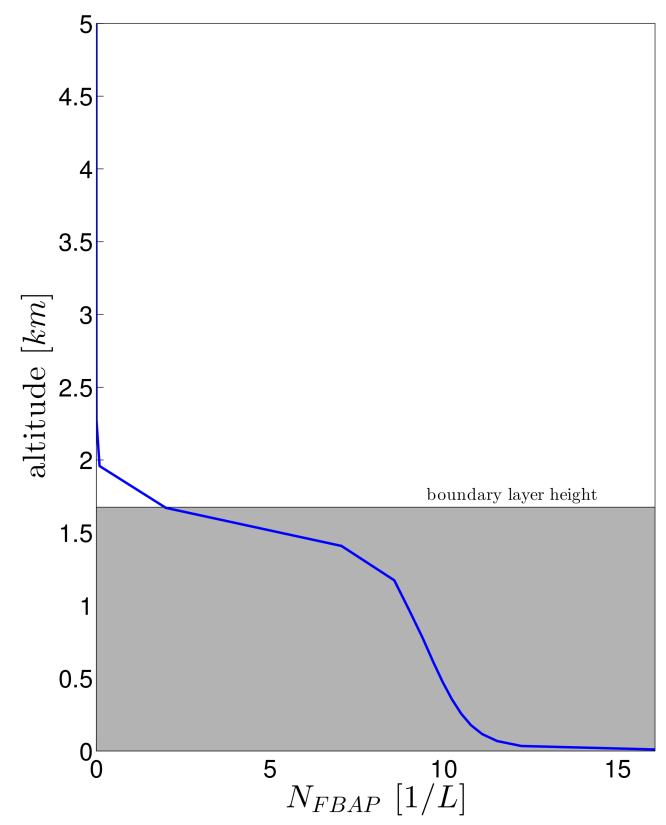

Figure 7. Exemplary vertical profile of simulated FBAP concentration within and above the planetary boundary layer for Karlsruhe at 28 August 2010, 14:00 UTC.

tween channel FL3_370 and the total FBAP concentration $N_{\mathrm{F}, \mathrm{c}}$ (channels FL1_280 and FL3_370). The average ratio between FL3_370 and FL1_280 + FL3_370 obtained from the WIBS data at Karlsruhe and Manchester during the study periods is 2.2. This factor is not taken into account in the comparison of the time series in Sect. 3.1, but corrected before applying Eq. (7) to the UV-APS data.

Analyzing the meteorological and surface parameters of the model output, it was found that a better correlation with the measured FBAP concentrations is achieved for specific humidity rather than relative humidity, as it was reported for previous field measurements (Gabey et al., 2010; Toprak and Schnaiter, 2013; Di Filippo et al., 2013). During the time period in July 2010, the measured FBAP concentrations vary in a narrow range of specific humidity, which is not reproduced by the literature-based simulation. For this reason, the July case study was removed from the regression analysis. A dependence on the LAI is assumed in order to take the seasonal change into account and to distinguish among various regions. A combination of LAI and specific humidity in the regression has the advantage of reducing the fitting parameters. The same relation was chosen by Heald and Spracklen (2009) for the previously discussed fungal spore emission parameterization. Additionally, surface temperature dependence as suggested by Di Filippo et al. (2013) is indicated by the time series and factored in a regression analysis. The parameters $\left(b_{1}=20.426\right.$ and $\left.b_{2}=3.93 \times 10^{4}\right)$ are estimated by minimizing the sum of all squared residuals and result in a multiple linear regression giving an emission flux 

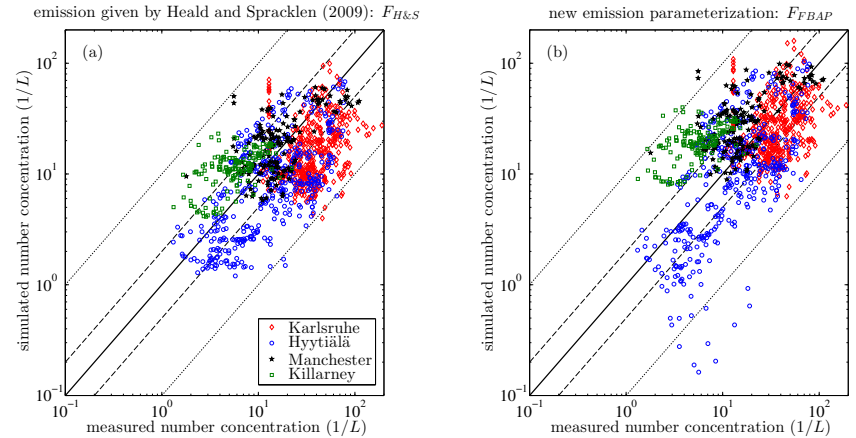

Figure 8. Comparison for all case studies: Measured FBAP number concentrations plotted vs. simulated number concentrations of (a) fungal spores based on the Heald and Spracklen (2009) emission flux and (b) FBAP based on the new emission parameterization derived from a multiple linear regression to FBAP concentrations. Solid black lines represent the $1: 1$ line, dashed lines the $1: 2$ line and dotted lines the $1: 10$ line.

$F_{\mathrm{E}}=F_{\mathrm{FBAP}}$ in $\mathrm{m}^{-2} \mathrm{~s}^{-1}$ fitted to FBAP measurements:

$F_{\mathrm{FBAP}}=b_{1}(T-275.82 \mathrm{~K})+b_{2} q_{\mathrm{v}} \mathrm{LAI}$,

where $T$ is the surface temperature in $\mathrm{K}, q_{\mathrm{v}}$ the specific humidity in $\mathrm{kg} \mathrm{kg}^{-1}$, and LAI the leaf area index in $\mathrm{m}^{2} \mathrm{~m}^{-2}$. The parameter inside the parentheses is related to an emission offset of the regression and covers unknown influences. The coefficient $b_{2}$ is approximately the same as the constants in the Heald and Spracklen (2009) emission for a particle diameter of $3 \mu \mathrm{m}$ given in Eq. (6). The additional temperature dependence in Eq. (8) increases the fungal spore emission for temperatures above $275.8 \mathrm{~K}$ and lowers the emission for temperatures below this value. The multiple linear regression (Eq. 8) yields a coefficient of determination of $R^{2}=0.4$.

\subsection{Results of simulations with the new emission parameterization}

$F_{\mathrm{FBAP}}$ was implemented into COSMO-ART and applied in simulations for all three episodes. Note that the extrapolation of the emission parameterization to regions especially in southern Europe, where ecosystems are different than at the stations where FBAP measurements where available, is uncertain and only valid under the assumption that temperature, specific humidity, and LAI are universal proxies for the biological and meteorological drivers of the emission strength. This hypothesis should be tested by additional observations in the future.

Figure 9 shows the emission flux for late August 2010, following the new parameterization, horizontally distributed over a model domain covering Europe. Here, averaged over land areas of the domain, $F_{\text {FBAP }}$ gives $1.03 \times 10^{3} \mathrm{~m}^{2} \mathrm{~s}^{-1}$. During July and October, the average flux is shifted to $1.4 \times 10^{3}$ and $0.4 \times 10^{3} \mathrm{~m}^{2} \mathrm{~s}^{-1}$, respectively, mainly as a result of seasonal changes of LAI and $T$ (not shown).

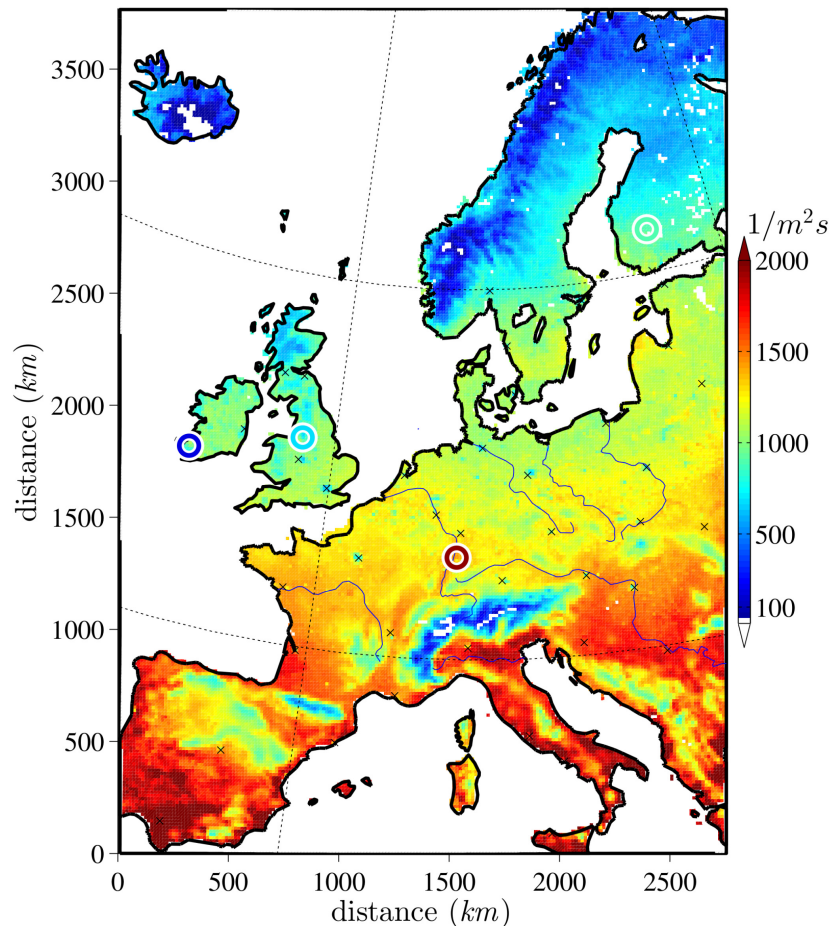

Figure 9. Average simulated FBAP emission flux $\left(F_{\mathrm{FBAP}}\right)$ in $\mathrm{m}^{-2} \mathrm{~s}^{-1}$ from 26 August to 1 September 2010 (excluding a spin-up period of $6 \mathrm{~h}$ ). Circles indicate the locations of the different FBAP measurement time series and the color within the white circles represents the mean emission flux calculated from FBAP measurements at each location.

When analyzing the temporal development of the simulated fungal spore/FBAP concentrations for each time series, $F_{\text {FBAP }}$ mostly results in a slightly higher number concentration than $F_{\mathrm{H} \& \mathrm{~S}}$ or $F_{\mathrm{S} \& \mathrm{D}}$ (Figs. 3 to 6 ). This is not the case for October 2010, where the $F_{\mathrm{FBAP}}$ concentrations are in the range of the literature-based concentrations. A sharp decrease on 15 October at Hyytiälä, which is not reflected by simulations with literature-based emission fluxes, is caused by a rapid temperature change.

For a statistical analysis of the results, the correlation coefficient $R$ and its confidence intervals, the NMB, and the RMSE have been calculated for the simulations with the three different emission functions (Table 3). The results indicate that the bias (given by the NMB) improves by the newly introduced emission function $F_{\mathrm{FBAP}}$, but not the correlation $R$ between simulated FBAP and observed FBAP concentrations which remains at the value of approximately 0.43 for the overall data set, whereas for the different time periods and stations, it varies between -0.17 and 0.66 (negative at only one station). Differences in $R$ are small between $N_{\mathrm{H} \& \mathrm{~S}}$ and $N_{\text {FBAP }}$, because both make use of emission rates as a function of almost the same parameters ( $N_{\mathrm{FBAP}}$ includes an additional $T$ dependence). The bias reduction and similar $R$ is also visible in Fig. 8. Parameters $b_{1}$ and $b_{2}$ in Eq. (8) 
Table 4. Leaf area index $\left(\mathrm{m}^{2} \mathrm{~m}^{-2}\right)$ from the climatological GLC2000 data set as used in the simulations compared to the nearest neighbor pixel of the 8-day, $1 \mathrm{~km}$ resolution MODIS LAI and to an average of the $1 \mathrm{~km}$ resolution MODIS LAI over a $20 \mathrm{~km} \times 20 \mathrm{~km}$ area centered on the station grid point. In addition, the standard deviation within that $20 \mathrm{~km} \times 20 \mathrm{~km}$ area is given. For the Manchester nearest neighbor $1 \mathrm{~km}$ grid point, no data are available for the given time period (n.d.).

\begin{tabular}{llrrrr}
\hline & & Karlsruhe & Hyytiälä & Manchester & Killarney \\
\hline \multirow{4}{*}{ 22 Jul-28 Jul 2010 } & 3.18 & 3.72 & - & - \\
& GLC2000 & 2.30 & 4.80 & - & - \\
& MODIS 1 km & 2.70 & 3.77 & - & - \\
& MODIS 20 km average & 1.64 & 1.34 & - & - \\
\hline \multirow{5}{*}{26 Aug-1 Sep 2010 20 km SD } & 2.94 & 3.40 & 2.87 & 2.06 \\
& GLC2000 & 3.46 & 1.59 & n.d. & 3.20 \\
& MODIS 1 km & 2.62 & 1.65 & 1.28 & 3.15 \\
& MODIS 20 km average & 1.48 & 1.10 & 0.66 & 1.97 \\
\hline & GLC2000 11 Oct-21 Oct 2010 km SD & 1.49 & 1.27 & - & - \\
& MODIS 1 km & 1.62 & 0.80 & - & - \\
& MODIS 20 km average & 1.41 & 1.32 & - & - \\
& MODIS 20 km SD & 0.93 & 0.96 & - & - \\
\hline
\end{tabular}

are chosen to give FBAP concentrations matching best with measured FBAP concentrations, and thus the reduction in NMB from $-44 \%\left(N_{\mathrm{H} \& \mathrm{~S}}\right)$ to $-0.4 \%\left(N_{\mathrm{FBAP}}\right)$. However, the bias reduction for the data set as a whole is coincident with larger positive and negative biases for four out of the eight episodes. Therefore, at the same time, the RMSE decreases only slightly from $26.2 \mathrm{~L}^{-1}\left(N_{\mathrm{H} \& \mathrm{~S}}\right)$ to $23.2 \mathrm{~L}^{-1}\left(N_{\mathrm{FBAP}}\right)$. At $T=275.82 \mathrm{~K}, F_{\mathrm{H} \& \mathrm{~S}}$ is equal to $F_{\mathrm{FBAP}}$ for typical values of LAI and $q_{\mathrm{v}}$ and temperatures above this threshold (as it is the case for almost all locations) shift $F_{\mathrm{FBAP}}$ to give a larger emission flux. At meteorological conditions present for the selected cases, the second part of Eq. (8) dominates over the first part by a factor of $\sim 4$ and therefore temperature changes have only a secondary influence on the emission flux. Hence, $R$ is similar for both emission parameterizations. Possible reasons for the only small improvements in $R$ and RMSE may be biases in the input parameters to the parameterizations or model errors in the processes affecting fungal spore concentrations. To investigate this, the LAI was compared to independent observations.

In Table 4, the LAI from the Global Land Cover 2000 database (European Commission, Joint Research Centre, 2003), which was used in the COSMO simulations, is compared to the MODIS LAI product (MCD14A2, MODIS collection 5; Knyazikhin et al., 1998) which is available at $1 \mathrm{~km}$ horizontal and 8-day temporal resolution. Both nearest neighbor pixels and averages over $20 \mathrm{~km} \times 20 \mathrm{~km}$ with standard deviations are calculated. For the Karlsruhe station and for Hyytiälä in July and October, a good agreement is obtained. For Hyytiälä and Manchester in August, MODIS indicates a factor of approximately 2 lower LAI than assumed in our simulations. For Killarney, in contrast, the MODIS LAI is about $50 \%$ higher. While this possible error in LAI can explain part of the discrepancy between simulated and observed
FBAP concentrations for Manchester, the bias in Hyytiälä is in the opposite direction, which is explainable by an error in LAI, and thus has to be related to other error sources. In Killarney, model and measurements agree rather well despite the LAI underprediction.

In addition, known deficiencies in the simulated boundary layer height may reduce the quality of the derived fit. The boundary layer height $h_{\mathrm{PBL}}$ had to be taken from the model simulations as it is not continuously available from observations at the stations. In the COSMO model, $h_{\mathrm{PBL}}$ is calculated by a bulk Richardson number method (Szintai and Kaufmann, 2008). It was shown for COSMO-2 simulations over the Swiss Plateau that this method overestimates $h_{\mathrm{PBL}}$ for convective boundary layers and strongly underestimates it for stable boundary layers (Collaud Coen et al., 2014).

Finally, the role of precipitation on FBAP concentrations is ambiguous, as already discussed in Sect. 3.1. At present, precipitation is not included as argument for the emission functions. Thus, they possibly neglect a driver of the variability.

\subsection{Contribution of fungal spore to near-surface aerosol composition}

For a comparison of simulated FBAP particles (in the model treated as fungal spores) to the dry aerosol chemical composition, the fungal spore mass concentration is estimated from the number concentration assuming monodisperse and spherical particles $\left(d=3 \mu \mathrm{m}, \rho_{P}=1 \mathrm{~g} \mathrm{~cm}^{-3}\right.$; Sect. 2.1). The horizontally distributed near-surface (approximately $10 \mathrm{~m}$ above ground) FBAP/fungal spore number concentration using $F_{\mathrm{FBAP}}$ is shown in Fig. 10. Concentrations simulated at the measurement locations are considerably lower than the high surface concentrations in the southern part of the model domain. 


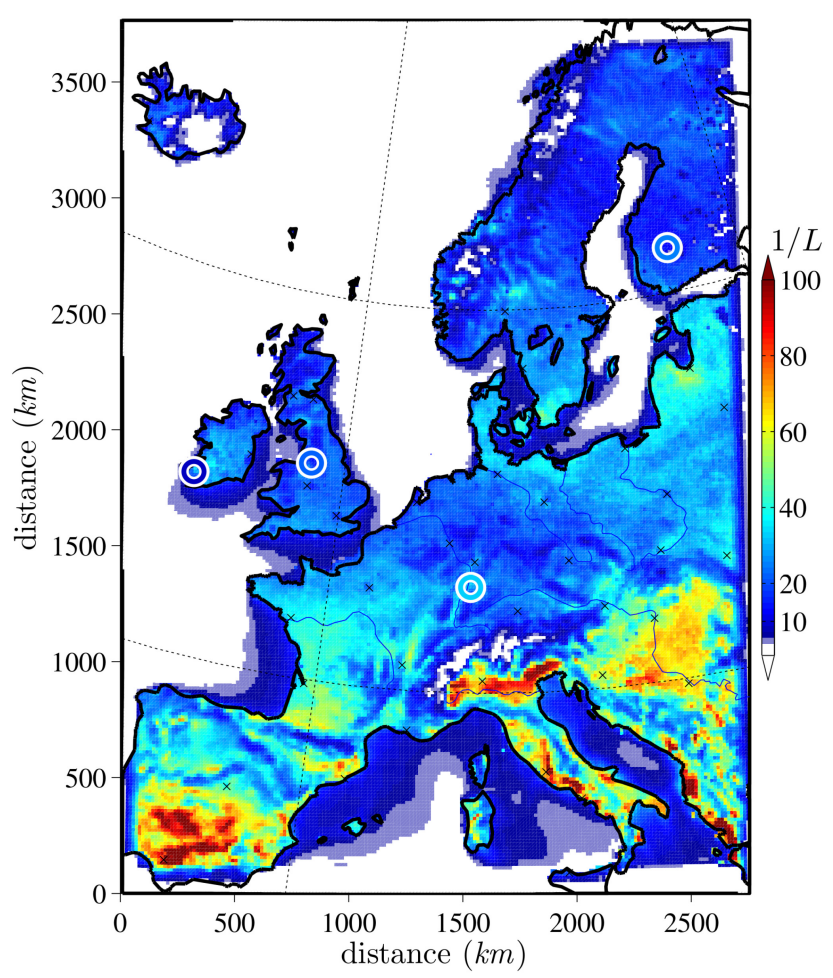

Figure 10. Horizontally distributed FBAP/fungal spore concentration in $1 \mathrm{~L}^{-1}$, emitted by $F_{\mathrm{FBAP}}$, in the lowest model layer, averaged from 26 August to 1 September 2010 (excluding a spin-up period of $6 \mathrm{~h}$ ). Circles indicate the locations of the different FBAP measurement time series and the color within the white circles represents the mean FBAP number concentration measured at each location.

The simulated mass concentrations of each chemical aerosol compound are averaged over the land areas of the model domain and the time period of late August 2010 (Fig. 11). The total aerosol mass concentration is approximately $2.5 \mu \mathrm{g} \mathrm{m}^{-3}$. Fungal spores distribute in the domain with an average number concentration of $26 \mathrm{~L}^{-1}$ over land. This corresponds to an average mass concentration of fungal spores of $0.37 \mu \mathrm{g} \mathrm{m}^{-3}$ which accounts for $15.4 \%$ of the total simulated aerosol mass. The total aerosol mass excludes mineral dust as one of the main contributors to the chemical aerosol composition, which might lower the fraction of fungal spore mass. A list of mass concentrations of the simulated chemical aerosol compounds, including fungal spores, at the four measurement sites, is given in Table 5. The mass fraction of fungal spores compared to the total aerosol simulated for these sites varies between 9 and $30 \%$.

\section{Discussion and conclusions}

FBAP measurements from four locations in Europe were compared with simulated concentrations of fungal spores and FBAP. Fluorescent particles are often observed to be most

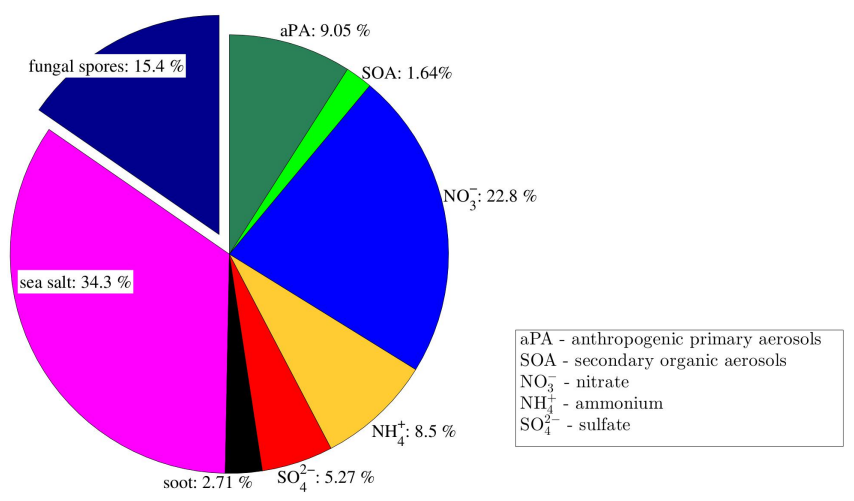

Figure 11. Near-surface chemical aerosol mass composition simulated by COSMO-ART, horizontally averaged over the land area in the model domain and temporally averaged from 26 August to 1 September 2010 (excluding a spin-up period of $6 \mathrm{~h}$ ).

abundant in the diameter range of $2-4 \mu \mathrm{m}$ (Huffman et al., 2010, 2012, 2013; Pöschl et al., 2010; Healy et al., 2012a; Toprak and Schnaiter, 2013). This diameter range for peak FBAP concentration matches closely with the modal size of many species of fungal spores known to be present in the atmospheric aerosol. Contrary to that, an increase in number concentration towards small particles has been reported for some FBAP measurement series, although only a small fraction of FBAP could be identified as bacteria cells (Gabey et al., 2011; Huffman et al., 2010). Therefore, FBAP cannot be equated with fungal spores, although the concentrations of these may agree well in many cases. This complicates the interpretation of the comparisons conducted in this study.

Comparison of simulations and measurements at four locations and the correlation of FBAP concentrations to meteorological and surface conditions are expected to be most robust when applying identical methods and conditions at all locations. These conditions were not fulfilled in our study. On one hand, site characteristics vary between the stations, which will influence the sensitivity of PBAP emission to surrounding conditions. On the other hand, the measurements are made with different instruments. The measurement series at Karlsruhe, Germany, are done with a WIBS-4 instrument which includes technical improvements compared to the WIBS-3 used at Manchester, UK, and Cork, Ireland (Gabey et al., 2010; Healy et al., 2012b). At Hyytiälä, Finland, and Killarney, Ireland, the UV-APS is used to determine the FBAP concentration. This variation may lead to different estimation of the FBAP concentration and within this case study WIBS may report FBAP at lower concentrations than UV-APS at different locations but similar meteorological conditions.

In this paper, fungal spore concentrations are calculated with the COSMO-ART atmospheric model by using literature-based emission parameterizations which are based on the adaptation of simulated global atmospheric concen- 
Table 5. Simulated aerosol mass concentrations for aerosol chemical components, including fungal spores, in $\mu \mathrm{g} \mathrm{m} \mathrm{m}^{-3}$ at the measuring sites as averages over the time period during August 2010.

\begin{tabular}{lrrrr}
\hline $\begin{array}{l}\text { Particle Mass } \\
\left(\mu \mathrm{g} \mathrm{m}^{-3}\right)\end{array}$ & $\begin{array}{r}\text { Karlsruhe, } \\
\text { Germany }\end{array}$ & $\begin{array}{r}\text { Hyytiälä, } \\
\text { Finland }\end{array}$ & $\begin{array}{r}\text { Manchester, } \\
\text { UK }\end{array}$ & $\begin{array}{r}\text { Killarney, } \\
\text { Ireland }\end{array}$ \\
\hline Fungal spores & 0.41 & 0.20 & 0.35 & 0.28 \\
Sea salt & 0.44 & 0.01 & 1.62 & 1.11 \\
Soot & 0.19 & 0.06 & 0.42 & 0.04 \\
$\mathrm{SO}_{4}^{2-}$ & 0.18 & 0.01 & 0.11 & 0.05 \\
$\mathrm{NH}_{4}^{+}$ & 0.44 & 0.01 & 0.14 & 0.07 \\
$\mathrm{NO}_{3}^{-}$ & 1.29 & 0.01 & 0.34 & 0.18 \\
$\mathrm{SOA}$ & 0.41 & 0.24 & 0.14 & 0.04 \\
$\mathrm{aPA}$ & 0.67 & 0.13 & 0.85 & 0.11 \\
\hline
\end{tabular}

tration to mannitol measurements or spore colony counts (Heald and Spracklen, 2009; Sesartic and Dallafior, 2011). Although mannitol concentration can include contributions from other PBAP (e.g., insects, bacteria, and algae) and from lower plants, the association to fungal spore concentration is reasonable (Di Filippo et al., 2013). Overall, the temporal development of the literature-based simulated fungal spore concentrations calculated by COSMO-ART approximately reproduces the measured FBAP concentrations. Some differences between simulated fungal spore and observed FBAP concentrations may be explainable by the usage of FBAP concentrations as a representative for fungal spores.

By using a time-independent (but spatially varying) emission flux $F_{\mathrm{S} \& \mathrm{D}}$, every development in the local temporal pattern arises from meteorological influences. A similar diurnal cycle develops between simulations with constant $\left(F_{\mathrm{S} \& \mathrm{D}}\right)$ and time-dependent $\left(F_{\mathrm{H} \& \mathrm{~S}}\right.$ and $\left.F_{\mathrm{FBAP}}\right)$ fungal spore emissions, but the diurnal amplitude differs to varying extent. Therefore, and from a correlation analysis with the inverse of the simulated boundary layer height, a diurnal cycle in the simulated fungal spore concentrations with a maximum between midnight and sunrise is shown to be influenced at least partly by boundary layer compression at night. However, measured FBAP concentrations are in some time periods not consistent with the simulated $h_{\mathrm{PBL}}$, which suggests that $N_{\mathrm{F}, \mathrm{c}}$ is additionally influenced, e.g., by possible increases in biological emission at night.

In this work, a new emission parameterization for FBAP particles is developed by a regression analysis to observations. As was formulated by Heald and Spracklen (2009), it depends on the specific humidity and the LAI, but is extended by temperature. The resulting concentrations have on the average a smaller NMB and a slightly smaller RMSE compared to the measured FBAP concentrations than the previously used fungal spore emission parameterizations, but variations in the measurements are not always captured by the simulation. Thus, the correlation coefficient remains low (0.43). Possible reasons include biases due to local conditions at the measurement stations, biases in the input parameters and model errors related to the transport, mixing and sink processes (including boundary layer turbulence and washout by precipitation). Future work including a long-term analysis of FBAP concentrations and environmental conditions may result in a further adjustment of the coefficients or reveal other parameters or functional dependencies driving the emission. Ideally, the observations would be split into a training data set and an evaluation data set, which was not possible until now due to the limited number of available observations.

Using the new emission parameterization on a model domain for Europe, FBAP emission fluxes are extrapolated from northern parts of the domain, where UV-LIF measurements were located, also to southern Europe. There, much higher emission fluxes occur in the simulation, partially caused by higher specific humidity, which is also the case for $F_{\mathrm{H} \& \mathrm{~S}}$, as well by temperature dependence in $F_{\mathrm{FBAP}}$. This extrapolation is without support from local southern European measurements, however, and thus further UV-LIF measurements are recommended for this region in southern Europe where fungal spore emission fluxes are potentially larger.

As a result of the relatively low model horizontal resolution of $14 \mathrm{~km}$, small-scale variations influencing fungal spore and FBAP emission at the measurement sites may not be resolved. Influences on a small scale might be due to an increased amount of fungi for the given vegetation type. When taking the LAI as a surrogate for the vegetation type, uncertainties may result from an insufficient relation to the presence of fungi or additional surrounding factors favoring fungi growth. Furthermore, variations in precipitation may not be captured by the model, which then may lead to biases in the fungal spore concentrations. The same holds for small wind gusts and convective cells which may have a strong influence on spore dispersion, but are not captured well in the model. An increase in FBAP and fungal spore concentration during or shortly after rain events (Huffman et al., 2013) could not be reproduced by the simulations, as this effect is not included in the emission parameterizations to an adequate extent. 
The module calculating the dispersion of FBAP/fungal spores does not include all processes of aerosol dynamics and cloud physics. Of the processes not included, only breaking up of spores can enhance their number concentration. Coagulation is neglected, as in most cases the FBAP/fungal spore number concentration is low and, hence, their collision is highly improbable. A coagulation of spores with other aerosol particles is more likely to happen, but not included in the simulations. Not much is known about the role of fungal spores and other biological particles in clouds and their ability to act as CCN.

The simulations presented in this paper highlight the importance of PBAP to the composition of atmospheric aerosol. Fungal spores, the focus of this paper, are among the main contributors to PBAP and therefore exert significant influence on aerosol loading. In this study, COSMO-ART is used to simulate all major chemical aerosol compounds except for mineral dust in a domain covering western Europe. When averaging the mass concentration horizontally across the land-covered part of the model domain and over all time steps of the simulation, fungal spores (assumed to be represented by FBAP) are among the major mass components (Fig. 11). However, the mass fraction of fungal spores might be overestimated here, as another major aerosol component, mineral dust, is not included, because the domain does not include any desert dust source areas. At the selected time periods, back trajectories with HYSPLIT (Draxler and Rolph, 2013) and the operational dust forecast with the BSC-DREAM8b model, operated by the Barcelona Supercomputing Center (http://www.bsc.es/earth-sciences/ mineral-dust-forecast-system/) suggest that transport of Sahara dust to the measurement stations is low (not shown), but influences the aerosol concentrations in southern Spain The emission from non-desert dust sources (in particular agricultural areas) is strongly episodical, as it is linked not only to meteorological conditions but also to human activity (e.g., tillage operations (Funk et al., 2008; Goossens et al., 2001), traffic). The magnitude of the local dust source strength is uncertain and not included in the model, as no validated emission parameterization is available at present. (Beuck et al., 2011) estimated that mineral dust (including both long-range transport and local sources) corresponds, on average, to $10 \%$ of $\mathrm{PM}_{10}$ concentrations in rural northwestern Germany, and $14 \%$ of $\mathrm{PM}_{10}$ concentrations in urban areas in this region.

The fungal spore mass concentration may reach up to $30 \%$ of simulated near-surface chemical aerosol mass components in rural areas of Finland (Table 5). In comparison, ratios of PBAP to total aerosol concentrations given in literature can assume similar values. The volume fraction of biological particles among particles larger than $0.2 \mu \mathrm{m}$ during 1 year of measurements at a remote site in Siberia reaches $28 \%$ on the average and at Mainz, Germany, the volume fraction amounts to $22 \%$ (Matthias-Maser et al., 2000). Both of these fractions agree well with simulated mass fractions of this study for comparable locations, although simulated concentrations given in this study are much lower than total PBAP number concentrations given in Matthias-Maser et al. (2000). In contrast, the number and mass fractions in the Amazonian basin are above $80 \%$ (Pöschl et al., 2010) and therefore much higher than in the urban and remote areas in this study (Pöschl et al., 2010).

PBAP and especially fungal spores might account for a major part of the aerosol loading. Local correlations between FBAP and ice nuclei number concentration (Tobo et al., 2013) show that future model studies of PBAP impacts on clouds are needed to determine their relevance to atmospheric ice nucleation.

Acknowledgements. We wish to thank Alexa Schnur for preliminary studies in connection with this paper, Max Bangert for technical support, and Miriam Sinnhuber for helpful discussions on the statistical analysis of our data. We would like to thank Christoph Knote and Dominik Brunner of EMPA for providing the emission data of the chemical compounds. We also wish to acknowledge P. Aalto, V. Hiltunen, T. Petäjä, C. Schumacher, and M. Kulmala for assistance gathering and analyzing data. We acknowledge support by the Deutsche Forschungsgemeinschaft and the Open-Access Publishing Fund of the Karlsruhe Institute of Technology. This research was funded by the Helmholtz Association through the Helmholtz Climate Initiative REKLIM and the President's Initiative and Networking Fund, and by DFG through project HO 4612/1-1 (FOR 1525 INUIT). J. A. Huffman acknowledges internal faculty funding from the University of Denver. J. A. Huffman, C. Pöhlker, and U. Pöschl acknowledge financial support from the Max Planck Society (MPG), the Max Planck Graduate Center with the Johannes Gutenberg University Mainz (MPGC), the LEC Geocycles Mainz, and the German Research Foundation (DFG PO1013/5-1, FOR 1525 INUIT).

The article processing charges for this open-access

publication were covered by a Research

Centre of the Helmholtz Association.

Edited by: M. Kanakidou

\section{References}

Ariya, P. A., Sun, J., Eltouny, N. A., Hudson, E. D., Hayes, C. T., and Kos, G.: Physical and chemical characterization of bioaerosols - Implications for nucleation processes, Int. Rev. Phys. Chem., 28, 1-32, 2009.

Aylor, D. E.: Settling speed of corn (Zea mays) pollen, J. Aerosol Sci., 33, 1601-1607, doi:10.1016/S0021-8502(02)00105-2, 2002.

Bartholomé, E. and Belward, A. S.: GLC2000: a new approach to global land cover mapping from Earth observation data, Int. J. Remote Sens., 26, 1959-1977, doi:10.1080/01431160412331291297, 2005.

Bauer, H., Schueller, E., Weinke, G., Berger, A., Hitzenberger, R., Marr, I. L., and Puxbaum, H.: Significant contributions of fungal spores to the organic carbon and to the aerosol mass balance of 
the urban atmospheric aerosol, Atmos. Environ., 42, 5542-5549, doi:10.1016/j.atmosenv.2008.03.019, 2008.

Beuck, H., Quass, U., Klemm, O., and Kuhlbusch, T. A. J.: Assessment of sea salt and mineral dust contributions to $\mathrm{PM}_{10}$ in NW Germany using tracer models and positive matrix factorization, Atmos. Environ., 45, 5813-5821, doi:10.1016/j.atmosenv.2011.07.010, 2011.

Bones, D. L., Henricksen, D. K., Mang, S. A., Gonsior, M., Bateman, A. P., Nguyen, T. B., Cooper, W. J., and Nizkorodov, S. A.: Appearance of strong absorbers and fluorophores in limonene$\mathrm{O}_{3}$ secondary organic aerosol due to $\mathrm{NH}_{4}^{+}$-mediated chemical aging over long time scales, J. Geophys. Res.-Atmos., 115, D05203, doi:10.1029/2009jd012864, 2010.

Brosseau, L. M., Vesley, D., Rice, N., Goodell, K., Nellis, M., and Hairston, P.: Differences in Detected Fluorescence Among Several Bacterial Species Measured with a Direct-Reading Particle Sizer and Fluorescence Detector, Aerosol Sci. Tech., 32, 545558, doi:10.1080/027868200303461, 2000.

Burch, M. and Levetin, E.: Effects of meteorological conditions on spore plumes, Int. J. Biometeorol., 46, 107-117, doi:10.1007/s00484-002-0127-1, 2002.

Burrows, S. M., Elbert, W., Lawrence, M. G., and Pöschl, U.: Bacteria in the global atmosphere - Part 1: Review and synthesis of literature data for different ecosystems, Atmos. Chem. Phys., 9, 9263-9280, doi:10.5194/acp-9-9263-2009, 2009.

Caruana, D. J.: Detection and analysis of airborne particles of biological origin: present and future, Analyst, 136, 4641-4652, doi:10.1039/c1an15506g, 2011.

Christner, B. C., Morris, C. E., Foreman, C. M., Cai, R., and Sands, D. C.: Ubiquity of Biological Ice Nucleators in Snowfall, Science, 319, 1214, doi:10.1126/science.1149757, 2008.

Collaud Coen, M., Praz, C., Haefele, A., Ruffieux, D., Kaufmann, P., and Calpini, B.: Determination and climatology of the planetary boundary layer height above the Swiss plateau by in situ and remote sensing measurements as well as by the COSMO-2 model, Atmos. Chem. Phys., 14, 13205-13221, doi:10.5194/acp14-13205-2014, 2014.

Creamean, J. M., Suski, K. J., Rosenfeld, D., Cazorla, A., DeMott, P. J., Sullivan, R. C., White, A. B., Ralph, F. M., Minnis, P., Comstock, J. M., Tomlinson, J. M., and Prather, K. A.: Dust and Biological Aerosols from the Sahara and Asia Influence Precipitation in the Western U.S, Science, 339, 1572-1578, doi:10.1126/science.1227279, 2013.

DeLeon-Rodriguez, N., Lathem, T. L., Rodriguez-R, L. M., Barazesh, J. M., Anderson, B. E., Beyersdorf, A. J., Ziemba, L. D., Bergin, M., Nenes, A., and Konstantinidis, K. T.: Microbiome of the upper troposphere: Species composition and prevalence, effects of tropical storms, and atmospheric implications, P. Natl. Acad. Sci., 110, 2575-2580, doi:10.1073/pnas.1212089110, 2013.

DeMott, P. J. and Prenni, A. J.: New Directions: Need for defining the numbers and sources of biological aerosols acting as ice nuclei, Atmos. Environ., 44, 1944-1945, 2010.

Després, V. R., Huffman, J. A., Burrows, S. M., Hoose, C., Safatov, A. S., Buryak, G., Fröhlich-Nowoisky, J., Elbert, W., Andreae, M. O., Pöschl, U., and Jaenicke, R.: Primary biological aerosol particles in the atmosphere: a review, Tellus B, 64, 15598, doi:10.3402/tellusb.v64i0.15598, 2012.
Di Filippo, P., Pomata, D., Riccardi, C., Buiarelli, F., and Perrino, C.: Fungal contribution to size-segregated aerosol measured through biomarkers, Atmos. Environ., 64, 132-140, doi:10.1016/j.atmosenv.2012.10.010, 2013.

Doms, G. and Schättler, U.: A Description of the Nonhydrostatic Regional COSMO-Model, Deutscher Wetterdienst, Offenbach, Germany, 2002.

Draxler, R. R. und Rolph, G. D.: HYSPLIT (HYbrid Single-Particle Lagrangian Integrated Trajectory), Model access via NOAA ARL READY Website (http://www.arl.noaa.gov/HYSPLIT.php, last access: 20 January 2015), NOAA Air Resources Laboratory, College Park, MD, USA, 2013.

Elbert, W., Taylor, P. E., Andreae, M. O., and Pöschl, U.: Contribution of fungi to primary biogenic aerosols in the atmosphere: wet and dry discharged spores, carbohydrates, and inorganic ions, Atmos. Chem. Phys., 7, 4569-4588, doi:10.5194/acp-7-4569-2007, 2007.

Fang, Z. G., Ouyang, Z. Y., Zheng, H., and Wang, X. K.: Concentration and size distribution of culturable airborne microorganisms in outdoor environments in Beijing, China, Aerosol Sci. Tech., 42, 325-334, doi:10.1080/02786820802068657, 2008.

Foot, V. E., Kaye, P. H., Stanley, W. R., Barrington, S. J., Gallagher, M., and Gabey, A.: Low-cost real-time multiparameter bio-aerosol sensors, P. Soc. Photo.-Opt. Ins., 7116, 71160I71112, 2008.

Forster, P., Ramaswamy, V., Artaxo, P., Berntsen, T., Betts, R., Fahey, D. W., Haywood, J., Lean, J., Lowe, D. C., Myhre, G., Nganga, J., Prinn, R., Raga, G., Schulz, M., and Dorland, R. V.: Changes in Atmospheric Constituents and in Radiative Forcing, in: Climate Change 2007: The Physical Science Basis. Contribution of Working Group I to the Fourth Assessment Report of the Intergovernmental Panel on Climate Change, edited by: Solomon, S., Qin, D., Manning, M., Chen, Z., Marquis, M., Averyt, K. B., Tignor, M., and Miller, H. L., Cambridge University Press, Cambridge, United Kingdom and New York, NY, USA, 2007.

Fountoukis, C. and Nenes, A.: ISORROPIA II: a computationally efficient thermodynamic equilibrium model for $\mathrm{K}^{+}$ $\mathrm{Ca}^{2+}-\mathrm{Mg}^{2+}-\mathrm{NH}_{4}^{+}-\mathrm{Na}^{+}-\mathrm{SO}_{4}^{2-}-\mathrm{NO}_{3}^{-}-\mathrm{Cl}^{-}-\mathrm{H}_{2} \mathrm{O}$ aerosols, Atmos. Chem. Phys., 7, 4639-4659, doi:10.5194/acp-7-4639-2007, 2007.

Fröhlich-Nowoisky, J., Burrows, S. M., Xie, Z., Engling, G., Solomon, P. A., Fraser, M. P., Mayol-Bracero, O. L., Artaxo, P., Begerow, D., Conrad, R., Andreae, M. O., Després, V. R., and Pöschl, U.: Biogeography in the air: fungal diversity over land and oceans, Biogeosciences, 9, 1125-1136, doi:10.5194/bg9-1125-2012, 2012.

Funk, R., Reuter, H. I., Hoffmann, C., Engel, W., and Öttl, D.: Effect of moisture on fine dust emission from tillage operations on agricultural soils, Earth Surf. Proc. Land., 33, 1851-1863, doi:10.1002/esp.1737, 2008.

Gabey, A. M., Gallagher, M. W., Whitehead, J., Dorsey, J. R., Kaye, P. H., and Stanley, W. R.: Measurements and comparison of primary biological aerosol above and below a tropical forest canopy using a dual channel fluorescence spectrometer, Atmos. Chem. Phys., 10, 4453-4466, doi:10.5194/acp-10-4453-2010, 2010.

Gabey, A. M., Stanley, W. R., Gallagher, M. W., and Kaye, P. H.: The fluorescence properties of aerosol larger than $0.8 \mu \mathrm{m}$ in ur- 
ban and tropical rainforest locations, Atmos. Chem. Phys., 11, 5491-5504, doi:10.5194/acp-11-5491-2011, 2011.

Gabey, A. M., Vaitilingom, M., Freney, E., Boulon, J., Sellegri, K., Gallagher, M. W., Crawford, I. P., Robinson, N. H., Stanley, W. R., and Kaye, P. H.: Observations of fluorescent and biological aerosol at a high-altitude site in central France, Atmos. Chem. Phys., 13, 7415-7428, doi:10.5194/acp-13-7415-2013, 2013.

Goossens, D., Gross, J., and Spaan, W.: Aeolian dust dynamics in agricultural land areas in Lower Saxony, Germany, Earth Surf. Proc. Land., 26, 701-720, doi:10.1002/esp.216, 2001.

Graham, B., Guyon, P., Maenhaut, W., Taylor, P. E., Ebert, M., Matthias-Maser, S., Mayol-Bracero, O. L., Godoi, R. H. M., Artaxo, P., Meixner, F. X., Moura, M. A. L., Rocha, C. H. E. D. A., Grieken, R. V., Glovsky, M. M., Flagan, R. C., and Andreae, M. O.: Composition and diurnal variability of the natural Amazonian aerosol, J. Geophys. Res.-Atmos., 108, 4765, doi:10.1029/2003jd004049, 2003.

Gregory, P. H.: The microbiology of the atmosphere, Plant Science Monographs, edited by: Polunin, N., Leonard Hill, London, 1961.

Haga, D. I., Iannone, R., Wheeler, M. J., Mason, R., Polishchuk, E. A., Fetch, T., van der Kamp, B. J., McKendry, I. G., and Bertram, A. K.: Ice nucleation properties of rust and bunt fungal spores and their transport to high altitudes where they can cause heterogeneous freezing, J. Geophys. Res. Atmos., 118, 7260-7272, doi:10.1002/jgrd.50556, 2013.

Hairston, P. P., Ho, J., and Quant, F. R.: Design of an instrument for real-time detection of bioaerosols using simultaneous measurement of particle aerodynamic size and intrinsic fluorescence, J. Aerosol Sci., 28, 471-482, 1997.

Hameed, A. A. A. and Khodr, M. I.: Suspended particulates and bioaerosols emitted from an agricultural non-point source, J. Environ. Monit., 3, 206-209, 2001.

Heald, C. L. and Spracklen, D. V.: Atmospheric budget of primary biological aerosol particles from fungal spores, Geophys. Res. Lett., 36, L09806, doi:10.1029/2009gl037493, 2009.

Healy, D. A., O'Connor, D. J., Burke, A. M., and Sodeau, J. R.: A laboratory assessment of the Waveband Integrated Bioaerosol Sensor (WIBS-4) using individual samples of pollen and fungal spore material, Atmos. Environ., 60, 534-543, doi:10.1016/j.atmosenv.2012.06.052, 2012a.

Healy, D. A., O'Connor, D. J., and Sodeau, J. R.: Measurement of the particle counting efficiency of the "Waveband Integrated Bioaerosol Sensor" model number 4 (WIBS-4), J. Aerosol Sci., 47, 94-99, doi:10.1016/j.jaerosci.2012.01.003, 2012b.

Healy, D. A., Huffman, J. A., O'Connor, D. J., Pöhlker, C., Pöschl, U., and Sodeau, J. R.: Ambient measurements of biological aerosol particles near Killarney, Ireland: a comparison between real-time fluorescence and microscopy techniques, Atmos. Chem. Phys., 14, 8055-8069, doi:10.5194/acp-14-80552014, 2014.

Helbig, N., Vogel, B., Vogel, H., and Fiedler, F.: Numerical modelling of pollen dispersion on the regional scale, Aerobiologia, 20, 3-19, doi:10.1023/b:aero.0000022984.51588.30, 2004.

Hoose, C. and Möhler, O.: Heterogeneous ice nucleation on atmospheric aerosols: a review of results from laboratory experiments, Atmos. Chem. Phys., 12, 9817-9854, doi:10.5194/acp-12-98172012, 2012.
Hoose, C., Kristjánsson, J. E., and Burrows, S. M.: How important is biological ice nucleation in clouds on a global scale?, Environ. Res. Lett., 5, 024009, doi:10.1088/1748-9326/5/2/024009, 2010a.

Hoose, C., Kristjánsson, J. E., Chen, J.-P., and Hazra, A.: A Classical-Theory-Based Parameterization of Heterogeneous Ice Nucleation by Mineral Dust, Soot, and Biological Particles in a Global Climate Model, J. Atmos. Sci., 67, 2483-2503, doi:10.1175/2010jas3425.1, 2010b.

Huffman, J. A., Treutlein, B., and Pöschl, U.: Fluorescent biological aerosol particle concentrations and size distributions measured with an Ultraviolet Aerodynamic Particle Sizer (UVAPS) in Central Europe, Atmos. Chem. Phys., 10, 3215-3233, doi:10.5194/acp-10-3215-2010, 2010.

Huffman, J. A., Sinha, B., Garland, R. M., Snee-Pollmann, A., Gunthe, S. S., Artaxo, P., Martin, S. T., Andreae, M. O., and Pöschl, U.: Size distributions and temporal variations of biological aerosol particles in the Amazon rainforest characterized by microscopy and real-time UV-APS fluorescence techniques during AMAZE-08, Atmos. Chem. Phys., 12, 11997-12019, doi:10.5194/acp-12-11997-2012, 2012.

Huffman, J. A., Prenni, A. J., DeMott, P. J., Pöhlker, C., Mason, R. H., Robinson, N. H., Fröhlich-Nowoisky, J., Tobo, Y., Després, V. R., Garcia, E., Gochis, D. J., Harris, E., Müller-Germann, I., Ruzene, C., Schmer, B., Sinha, B., Day, D. A., Andreae, M. O., Jimenez, J. L., Gallagher, M., Kreidenweis, S. M., Bertram, A. K., and Pöschl, U.: High concentrations of biological aerosol particles and ice nuclei during and after rain, Atmos. Chem. Phys., 13, 6151-6164, doi:10.5194/acp-13-6151-2013, 2013.

Jacobson, M. Z. and Streets, D. G.: Influence of future anthropogenic emissions on climate, natural emissions, and air quality, J. Geophys. Res.-Atmos., 114, D08118, 10.1029/2008jd011476, 2009.

Jaenicke, R.: Über die Dynamik atmosphärischer Aitkenteilchen, in: Berichte der Bunsengesellschaft für physikalische Chemie, 82, 1198-1202, doi:10.1002/bbpc.19780821126, 1978.

Jaenicke, R., Matthias-Maser, S., and Gruber, S.: Omnipresence of biological material in the atmosphere, Environ. Chem., 4, 217220, doi:10.1071/EN07021, 2007.

Jones, A. M. and Harrison, R. M.: The effects of meteorological factors on atmospheric bioaerosol concentrations - a review, Sci. Total Environ., 326, 151-180, doi:10.1016/j.scitotenv.2003.11.021, 2004.

Kaye, P., Stanley, W. R., Hirst, E., Foot, E. V., Baxter, K. L., and Barrington, S. J.: Single particle multichannel bioaerosol fluorescence sensor, Opt. Express, 13, 3583-3593, doi:10.1364/opex.13.003583, 2005.

Knote, C., Brunner, D., Vogel, H., Allan, J., Asmi, A., Äijälä, M., Carbone, S., van der Gon, H. D., Jimenez, J. L., KiendlerScharr, A., Mohr, C., Poulain, L., Prévôt, A. S. H., Swietlicki, E., and Vogel, B.: Towards an online-coupled chemistry-climate model: evaluation of trace gases and aerosols in COSMO-ART, Geosci. Model Dev., 4, 1077-1102, doi:10.5194/gmd-4-10772011, 2011.

Knyazikhin, Y., Martonchik, J. V., Myneni, R. B., Diner, D. J., and Running, S. W.: Synergistic algorithm for estimating vegetation canopy leaf area index and fraction of absorbed photosynthetically active radiation from MODIS and MISR data, J. Geophys. Res.-Atmos., 103, 32257-32275, doi:10.1029/98JD02462, 1998. 
Kuenen, J., Denier van der Gon, H., Visschedijk, A., van der Brugh, H., and Gijlswijk, R.: MACC European emission inventory for the years 2003-2007, TNO, Utrecht, Netherlands, TNO-060-UT2011-00588, 49, 2011.

Lee, H. J., Laskin, A., Laskin, J., and Nizkorodov, S. A.: ExcitationEmission Spectra and Fluorescence Quantum Yields for Fresh and Aged Biogenic Secondary Organic Aerosols, Environ. Sci. Technol., 47, 5763-5770, doi:10.1021/es400644c, 2013.

Lin, W.-H. and Li, C.-S.: Size Characteristics of Fungus Allergens in the Subtropical Climate, Aerosol Sci. Tech., 25, 93-100, doi:10.1080/02786829608965382, 1996.

Lundgren, K., Vogel, B., Vogel, H., and Kottmeier, C.: Direct radiative effects of sea salt for the Mediterranean region under conditions of low to moderate wind speeds, J. Geophys. Res.-Atmos., 118, 1906-1923, doi:10.1029/2012jd018629, 2013.

Mahowald, N., Jickells, T. D., Baker, A. R., Artaxo, P., BenitezNelson, C. R., Bergametti, G., Bond, T. C., Chen, Y., Cohen, D. D., Herut, B., Kubilay, N., Losno, R., Luo, C., Maenhaut, W., McGee, K. A., Okin, G. S., Siefert, R. L., and Tsukuda, S.: Global distribution of atmospheric phosphorus sources, concentrations and deposition rates, and anthropogenic impacts, Global Biogeochem. Cy., 22, GB4026, doi:10.1029/2008gb003240, 2008.

Martin, S. T., Andreae, M. O., Artaxo, P., Baumgardner, D., Chen, Q., Goldstein, A. H., Guenther, A., Heald, C. L., Mayol-Bracero, O. L., McMurry, P. H., Pauliquevis, T., Pöschl, U., Prather, K. A., Roberts, G. C., Saleska, S. R., Silva Dias, M. A., Spracklen, D. V., Swietlicki, E., and Trebs, I.: Sources and properties of Amazonian aerosol particles, Rev. Geophys., 48, RG2002, doi:10.1029/2008rg000280, 2010.

Matthias-Maser, S., Obolkin, V., Khodzer, T., and Jaenicke, R.: Seasonal variation of primary biological aerosol particles in the remote continental region of Lake Baikal/Siberia, Atmos. Environ., 34, 3805-3811, doi:10.1016/s1352-2310(00)00139-4, 2000.

Morris, C. E., Georgakopoulos, D. G., and Sands, D. C.: Ice nucleation active bacteria and their potential role in precipitation, J. Phys. IV France, 121, 87-103, 2004.

Morris, C. E., Sands, D. C., Glaux, C., Samsatly, J., Asaad, S., Moukahel, A. R., Gonçalves, F. L. T., and Bigg, E. K.: Urediospores of rust fungi are ice nucleation active at $>-10{ }^{\circ} \mathrm{C}$ and harbor ice nucleation active bacteria, Atmos. Chem. Phys., 13, 4223-4233, doi:10.5194/acp-13-4223-2013, 2013.

Murray, B. J., O'Sullivan, D., Atkinson, J. D., and Webb, M. E.: Ice nucleation by particles immersed in supercooled cloud droplets, Chem. Soc. Rev., 41, 6519-6554, 2012.

O'Connor, D. J., Healy, D. A., Hellebust, S., Buters, J. T. M., and Sodeau, J. R.: Using the WIBS-4 (Waveband Integrated Bioaerosol Sensor) technique for the on-line detection of pollen grains, Aerosol Sci. Tech., 48, 341-349, doi:10.1080/02786826.2013.872768, 2014.

Olson, D. M., Dinerstein, E., Wikramanayake, E. D., Burgess, N. D., Powell, G. V. N., Underwood, E. C., D’Amico, J. A., Itoua, I., Strand, H. E., Morrison, J. C., Loucks, C. J., Allnutt, T. F., Ricketts, T. H., Kura, Y., Lamoreux, J. F., Wettengel, W. W., Hedao, P., and Kassem, K. R.: Terrestrial Ecoregions of the World: A New Map of Life on Earth, Bioscience, 51, 933-938, doi:10.1641/0006-3568(2001)051[0933:teotwa]2.0.co;2, 2001.

Pan, Y.-1., Holler, S., Chang, R. K., Hill, S. C., Pinnick, R. G., Niles, S., and Bottiger, J. R.: Single-shot fluorescence spec- tra of individual micrometer-sized bioaerosols illuminated by a 351- or a 266-nm ultraviolet laser, Opt. Lett., 24, 116-118, doi:10.1364/ol.24.000116, 1999.

Penner, J. E.: Carbonaceous aerosols influencing atmospheric radiation: black and organic carbon, in: Aerosol Forcing of Climate, edited by: Charlson, R. J. and Heintzenberg, J., John Wiley and Sons, Chichester, 91-108, 1995.

Petters, M. D. and Kreidenweis, S. M.: A single parameter representation of hygroscopic growth and cloud condensation nucleus activity, Atmos. Chem. Phys., 7, 1961-1971, doi:10.5194/acp-71961-2007, 2007.

Pöhlker, C., Huffman, J. A., and Pöschl, U.: Autofluorescence of atmospheric bioaerosols - fluorescent biomolecules and potential interferences, Atmos. Meas. Tech., 5, 37-71, doi:10.5194/amt-537-2012, 2012.

Pöhlker, C., Huffman, J. A., Förster, J.-D., and Pöschl, U.: Autofluorescence of atmospheric bioaerosols: spectral fingerprints and taxonomic trends of pollen, Atmos. Meas. Tech., 6, 3369-3392, doi:10.5194/amt-6-3369-2013, 2013.

Pope, F. D.: Pollen grains are efficient cloud condensation nuclei, Environ. Res. Lett., 5, 044015, doi:10.1088/17489326/5/4/044015, 2010.

Pöschl, U., Martin, S. T., Sinha, B., Chen, Q., Gunthe, S. S., Huffman, J. A., Borrmann, S., Farmer, D. K., Garland, R. M., Helas, G., Jimenez, J. L., King, S. M., Manzi, A., Mikhailov, E., Pauliquevis, T., Petters, M. D., Prenni, A. J., Roldin, P., Rose, D., Schneider, J., Su, H., Zorn, S. R., Artaxo, P., and Andreae, M. O.: Rainforest Aerosols as Biogenic Nuclei of Clouds and Precipitation in the Amazon, Science, 329, 15131516, doi:10.1126/science.1191056, 2010.

Prenni, A. J., Petters, M. D., Kreidenweis, S. M., Heald, C. L., Martin, S. T., Artaxo, P., Garland, R. M., Wollny, A. G., and Pöschl, U.: Relative roles of biogenic emissions and Saharan dust as ice nuclei in the Amazon basin, Nature Geosci., 2, 402-405, 2009.

Prenni, A. J., Tobo, Y., Garcia, E., DeMott, P. J., Huffman, J. A., McCluskey, C. S., Kreidenweis, S. M., Prenni, J. E., Pöhlker, C., and Pöschl, U.: The impact of rain on ice nuclei populations at a forested site in Colorado, Geophys. Res. Lett., 40, 227-231, doi:10.1029/2012g1053953, 2013.

Ramankutty, N., Evan, A. T., Monfreda, C., and Foley, J. A.: Farming the planet: 1. Geographic distribution of global agricultural lands in the year 2000, Global Biogeochem. Cy., 22, GB1003, doi:10.1029/2007gb002952, 2008.

Reponen, T., Grinshpun, S. A., Conwell, K. L., Wiest, J., and Anderson, M.: Aerodynamic vs. physical size of spores: Measurement and implication for respiratory deposition, Grana, 40, 119-125, doi:10.1080/00173130152625851, 2001.

Rinke, R.: Parametrisierung des Auswaschens von Aerosolpartikeln durch Niederschlag, PhD, Inst. für Meteorol. und Klimaforsch., Univ. Karlsruhe (TH), Karlsruhe, Germany, 2008.

Robinson, N. H., Allan, J. D., Huffman, J. A., Kaye, P. H., Foot, V. E., and Gallagher, M.: Cluster analysis of WIBS single-particle bioaerosol data, Atmos. Meas. Tech., 6, 337-347, doi:10.5194/amt-6-337-2013, 2013.

Saari, S. E., Putkiranta, M. J., and Keskinen, J.: Fluorescence spectroscopy of atmospherically relevant bacterial and fungal spores and potential interferences, Atmos. Environ., 71, 202209, doi:10.1016/j.atmosenv.2013.02.023, 2013. 
Schell, B., Ackermann, I. J., Hass, H., Binkowski, F. S., and Ebel, A.: Modeling the formation of secondary organic aerosol within a comprehensive air quality model system, J. Geophys. Res.Atmos., 106, 28275-28293, doi:10.1029/2001jd000384, 2001.

Schumacher, C. J., Pöhlker, C., Aalto, P., Hiltunen, V., Petäjä, T., Kulmala, M., Pöschl, U., and Huffman, J. A.: Seasonal cycles of fluorescent biological aerosol particles in boreal and semiarid forests of Finland and Colorado, Atmos. Chem. Phys., 13, 11987-12001, doi:10.5194/acp-13-11987-2013, 2013.

Seinfeld, J. H. and Pandis, S. N.: Atmospheric Chemistry and Physics - From Air Pollution to Climate Change (2nd Edition), John Wiley \& Sons, Hoboken, New Jersey, USA, 2006.

Sesartic, A. and Dallafior, T. N.: Global fungal spore emissions, review and synthesis of literature data, Biogeosciences, 8, 11811192, doi:10.5194/bg-8-1181-2011, 2011.

Sesartic, A., Lohmann, U., and Storelvmo, T.: Bacteria in the ECHAM5-HAM global climate model, Atmos. Chem. Phys., 12, 8645-8661, doi:10.5194/acp-12-8645-2012, 2012.

Shaffer, B. T. and Lighthart, B.: Survey of Culturable Airborne Bacteria at Four Diverse Locations in Oregon: Urban, Rural, Forest, and Coastal, Microb. Ecol., 34, 167-177, 1997.

Spracklen, D. V. and Heald, C. L.: The contribution of fungal spores and bacteria to regional and global aerosol number and ice nucleation immersion freezing rates, Atmos. Chem. Phys., 14, 90519059, doi:10.5194/acp-14-9051-2014, 2014.

Szintai, B. and Kaufmann, P.: TKE as a Measure of Turbulence, COSMO Newsletter, 8, 2-10, 2008.

Tobo, Y., Prenni, A. J., DeMott, P. J., Huffman, J. A., McCluskey, C. S., Tian, G., Pöhlker, C., Pöschl, U., and Kreidenweis, S. M.: Biological aerosol particles as a key determinant of ice nuclei populations in a forest ecosystem, J. Geophys. Res.-Atmos., 118, 10100-10110, doi:10.1002/jgrd.50801, 2013.
Toprak, E. and Schnaiter, M.: Fluorescent biological aerosol particles measured with the Waveband Integrated Bioaerosol Sensor WIBS-4: laboratory tests combined with a one year field study, Atmos. Chem. Phys., 13, 225-243, doi:10.5194/acp-13225-2013, 2013.

Trail, F., Gaffoor, I., and Vogel, S.: Ejection mechanics and trajectory of the ascospores of Gibberella zeae (anamorph Fuarium graminearum), Fungal Genet. Biol., 42, 528-533, doi:10.1016/j.fgb.2005.03.008, 2005.

Vogel, B., Vogel, H., Bäumer, D., Bangert, M., Lundgren, K., Rinke, R., and Stanelle, T.: The comprehensive model system COSMOART - Radiative impact of aerosol on the state of the atmosphere on the regional scale, Atmos. Chem. Phys., 9, 8661-8680, doi:10.5194/acp-9-8661-2009, 2009.

Vogel, H., Pauling, A., and Vogel, B.: Numerical simulation of birch pollen dispersion with an operational weather forecast system, Int. J. Biometeorol., 52, 805-814, doi:10.1007/s00484-0080174-3, 2008.

Winiwarter, W., Bauer, H., Caseiro, A., and Puxbaum, H.: Quantifying emissions of primary biological aerosol particle mass in Europe, Atmos. Environ., 43, 1403-1409, doi:10.1016/j.atmosenv.2008.01.037, 2009.

Yamamoto, N., Bibby, K., Qian, J., Hospodsky, D., Rismani-Yazdi, H., Nazaroff, W. W., and Peccia, J.: Particle-size distributions and seasonal diversity of allergenic and pathogenic fungi in outdoor air, ISME J., 6, 1801-1811, 2012. 